\title{
BIOCHAR PRODUCTION FROM WASTE BIOMASS: CHARACTERIZATION AND EVALUATION FOR AGRONOMIC AND ENVIRONMENTAL APPLICATIONS
}

\author{
Frantseska-Maria Pellera, Panagiotis Regkouzas, Ioanna Manolikaki and Evan \\ Diamadopoulos *
}

School of Environmental Engineering, Technical University of Crete, 73100 Chania, Greece
Article Info:
Received:
12 March 2021
Revised:
26 November 2021
Accepted:
26 November 2021
Available online:
19 December 2021
Keywords:
Chemical properties
Physical properties
Adsorbent
Amendment
Germination
Remediation

\begin{abstract}
This study focused on the valorization of different types of waste biomass through biochar production at two pyrolysis temperatures $\left(400\right.$ and $\left.600^{\circ} \mathrm{C}\right)$. The different feedstocks being used included three materials of municipal origin, specifically two types of sewage sludge and the organic fraction of municipal solid waste, and three materials of agroindustrial origin, specifically grape pomace, rice husks and exhausted olive pomace. The scope of the research was to characterize the resulting materials, in order to evaluate their possible uses in agronomic and environmental applications. Biochar characterization included the determination of several physical and chemical parameters, while germination assays were also carried out. Under the investigated conditions, both pyrolysis temperature and feedstock type appeared to significantly affect biochar characteristics, leading to the production of versatile materials, with many different possible uses. Specifically, results implied that biochars of both municipal and agroindustrial origin have the potential to effectively be used in applications including the improvement of soil characteristics, carbon sequestration, the removal of organic and inorganic contaminants from aqueous media, and the remediation of contaminated soil, with the degree of suitability of each material to each specific use being estimated to differ depending on its particular characteristics. For this reason, with these characteristics in mind, before proceeding to larger scale applications a cautious selection of materials should be conducted.
\end{abstract}

\section{INTRODUCTION}

In recent years, the continuous increase of wastes has directed global interest to the development of sustainable waste management strategies. One of the most representative examples of rapidly increasing waste production is that of municipal waste (Elkhalifa et al., 2019). In fact, both municipal solid waste (MSW) and sewage sludge (SS) obtained from municipal wastewater treatment plants constitute two priority waste categories which, as a result of the increasing population in urban centers, are continuously generated in large quantities. The importance of these wastes comes not only from their high production rates, but also from their particular composition, since they often contain various potentially toxic elements (e.g. potentially toxic metal(loid)s, pathogens, organic contaminants, etc.) (Agrafioti et al., 2013; Ahmad et al., 2014; Gunarathne et al., 2019; Rybova et al., 2018).

Waste and by-products originating from agroindustrial activities represent another category of residual materials with a quite elevated generation rate, especially in countries where agriculture and agro-industries represent important sectors of the economy (Fountoulakis et al., 2008). The wine and olive oil production and the rice processing industries are among the most profitable agroindustries, yet they generate considerable quantities of wastes and by-products. In EU-28 in 2019, the production of grapes for wine, olives for oil, and rice, reached 22,370, 10,255 and 2,841 thousand tonnes, respectively, with Greece accounting for 466, 935 and 222 thousand tonnes, respectively (EUROSTAT, 2020).

Lately, more and more attention has been focusing on the use of waste as resources for both energy and added-value materials, in the framework of a circular economy (Elkhalifa et al., 2019). In this context, waste biomass of not only municipal, but also of agroindustrial origin, could prove quite promising due to both composition and availability.

Converting waste into biochar through pyrolysis is considered a viable method for valorizing such residual 
resources (Gunarathne et al., 2019). The reason for the increasing interest in biochar comes from the fact that, apart from being an effective method for reducing health and environmental hazards associated with waste biomass, it can find various beneficial applications, including its use as an adsorbent for contaminant removal from water or wastewater, as an amendment for improving soil characteristics and for remediation of contaminated sites (Ahmad et al., 2014; Aller, 2016). This high versatility of biochar is attributed to its wide variety of properties, which depend not only on the pyrolysis conditions being adopted, but also on the type of feedstock being used (Aller, 2016; Fryda et al., 2019; Rehrah et al., 2016).

Biochar characterization usually includes the investigation of several properties, with each one of them playing a different role in the potential biochar applications. For example, proximate and ultimate composition can give insights regarding biochar stability in soil. High fixed carbon contents, as well as high aromaticity and hydrophobicity have been associated with greater carbon stability and thus a greater ability of biochars to act as carbon sequestration agents (Ahmad et al., 2012; Tag et al., 2016). Such biochars are usually produced at higher temperatures and are more resistant to microbial degradation and mineralization. On the other hand, biochars that are produced at lower temperatures are more hydrophilic and can contribute to increasing soil water holding capacity (Rehrah et al., 2016; Zhao et al., 2017). Determining the electrical conductivity of biochars can reveal their effect on soil quality and fertility (Rehrah et al., 2016; Zhao et al., 2017), while biochars with a large amount of surface functional groups and a high cation exchange capacity can be used in soils for enhancing nutrient exchange sites and for preventing nutrient leaching (Tag et al., 2016; Zhao et al., 2017). Biochar $\mathrm{pH}$ can be very important for both agronomic and environmental applications. Since biochars are often moderately to highly alkaline, they can exert liming effects resulting in acid soil amelioration, immobilization of metals in contaminated soils and removal of them from aqueous media (Ahmad et al., 2014). The point of zero charge $\left(\mathrm{pH}_{\mathrm{PZC}}\right)$ is another very important characteristic in terms of contaminant removal from water and wastewater. It represents the $\mathrm{pH}$ value at which the surface charge of biochar is zero. More specifically, when the $\mathrm{pH}$ of the solution is greater than $\mathrm{pH}_{\mathrm{PZC}}$, the biochar is negatively charged and tends to attract cations, while when the $\mathrm{pH}$ of the solution is lower than $\mathrm{pH}_{\mathrm{PZC}}$, the biochar is positively charged and tends to attract anions ( $\mathrm{Li}$ et al., 2017; Tan et al., 2015). Moreover, while biochars produced at higher pyrolysis temperatures tend to be more effective for sorbing organic contaminants, as a result of their usually higher surface area, microporosity and hydrophobicity, those generated at lower temperatures are more prone to sorbing inorganic and polar contaminants through electrostatic interactions, precipitation/co-precipitation, as well as interaction with surface functional groups (Ahmad et al., 2014). All the above, highlight the importance of a comprehensive characterization, and of the use of such information to thoroughly evaluate biochars for their use in more than one types of applications at the same time. Such an ap- proach will be helpful in directing research towards the most efficient, effective and profitable solutions. In the literature there is a limited number of studies (Ibn Ferjani et al., 2019; Oh et al., 2012; Pariyar et al., 2020; Stylianou et al., 2020; Taskin et al., 2019) referring to biochar characterization aiming at both agronomic and environmental uses.

The present study contributes to this regard, by characterizing and investigating biochars of different natures regarding their potential environmental and agronomic uses Six different waste biomass feedstocks, specifically three of municipal origin, namely two types of sewage sludge and the organic fraction of municipal solid waste, and three of agroindustrial origin, namely grape pomace, rice husks and exhausted olive pomace, were used to produce biochar through pyrolysis at two different temperatures, i.e. 400 and $600^{\circ} \mathrm{C}$. The resulting carbonaceous materials were then characterized through a series of physical and chemical analyses, and used in germination assays, in order to reveal eventual beneficial, inhibitory or toxic features. The objective of the study is to ultimately be able to assess, on the basis of the obtained results, the potential uses of each biochar for either agronomic or environmental purposes.

\subsection{Nomenclature}

$\begin{array}{ll}\text { CEC } & \text { cation exchange capacity } \\ \text { EC } & \text { electrical conductivity } \\ \text { EOP } & \text { exhausted olive pomace } \\ \text { FC } & \text { fixed carbon } \\ \text { FT-IR } & \text { Fourier Transform Infrared spectra } \\ \text { GP } & \text { grape pomace } \\ \text { OF } & \text { organic fraction }\end{array}$

OFMSW organic fraction of municipal solid waste

pHPZC point of zero charge

PTMs potentially toxic metal(loid)s

SS sewage sludge

SSC sewage sludge from Chania

SSP sewage sludge from Psyttalia

$\mathrm{RH} \quad$ rice husks

VM volatile matter

\section{MATERIALS AND METHODS}

\subsection{Waste biomass feedstocks}

Six types of biomass were used as feedstocks for biochar production, namely two types of digested sewage sludge (SS), the organic fraction of municipal solid waste (OFMSW), grape pomace (GP), rice husks $(\mathrm{RH})$ and exhausted olive pomace (EOP). The first SS sample (SSC) was obtained from the Municipal Wastewater Treatment Plant of Chania, Crete, Greece and consisted of anaerobically digested SS that had been mechanically dewatered. The second SS sample (SSP) was obtained from the Psyttalia Wastewater Treatment Plant, Athens, Greece and consisted of anaerobically digested SS that had been dewatered through drying. OFMSW originated from the Inter-municipal Enterprise of Solid Waste Management (DEDISA) of Chania. GP was obtained from a local winery in Chania, while $\mathrm{RH}$ originated from a rice mill in northern 
Greece. Finally, EOP was obtained from the local food industry Mills of Crete.

Prior to pyrolysis the six materials were subjected to a preparation procedure, which differed slightly depending on the material. More specifically, SSC was initially oven dried at $60 \pm 5^{\circ} \mathrm{C}$ for 3 days and then ground to a particle size lower than $500 \mu \mathrm{m}$, while for SSP the procedure included only the grinding step, since the material was already dry when received. In the case of OFMSW, the sample was initially manually screened, aiming at removing any unwanted materials (e.g. inert, plastic, metallic and/or hazardous materials) and at leaving only putrescibles and (tissue) paper. Afterwards, the sample was oven dried at $60 \pm 5^{\circ} \mathrm{C}$ for 3 days, further screened for unwanted materials that may have remained after the first screening, and finally ground to a particle size lower than $500 \mu \mathrm{m}$. GP was prepared through oven drying and grinding, as earlier mentioned, while $\mathrm{RH}$ and EOP were received as agro-industrial productsand were not further processed. The grinding procedures were carried out using either a food processor or a universal cutting mill (Pulverisette 19, Fritsch). After the above mentioned preparation procedures, all biomass feedstocks were stored in closed containers until further use.

\subsection{Biochar preparation}

The pyrolysis process was carried out in a muffle furnace (Linn High Therm) at two different temperatures, 400 and $600^{\circ} \mathrm{C}$, with a heating rate of $3^{\circ} \mathrm{C} / \mathrm{min}$ and a residence period (at the target temperature) of $1 \mathrm{~h}$. These two pyrolysis temperatures were chosen on the basis that below $300^{\circ} \mathrm{C}$ pyrolysis of biomass may be incomplete, while above $700^{\circ} \mathrm{C}$ the amount of carbon left on char is minimum. Inert conditions were ensured by purging nitrogen in the furnace interior with a flow rate of $200 \mathrm{~L} / \mathrm{h}$. After cooling, the resulting materials were subjected to a washing procedure with the purpose of removing excess ash and eventual organic substances that may have been produced during pyrolysis. This procedure was adopted as a step in the production process aiming at limiting potential toxic effects of the biochars in future environmental and agronomic applications. In brief, the samples were mixed with deionized water at a solid/liquid ratio of $1 / 15 \mathrm{~g} / \mathrm{mL}$ and agitated on an orbital shaking table at $200 \mathrm{rpm}$ for $1 \mathrm{~h}$. The solid and liquid fractions were then separated through vacuum filtration and the solid fractions were finally rinsed with deionized water and oven dried. The final products were homogenized using a mortar and ultimately stored in closed containers until use. Twelve types of biochar were obtained through the above-mentioned procedure, which are presented in Table 1.

\subsection{Characterization and analytical methods}

The biochar materials were characterized regarding certain basic properties, aiming at evaluating their potential use in agronomic and environmental applications. These include proximate (ash, volatile matter (VM), fixed carbon (FC)) and ultimate (CHNS\%) composition, contents in mineral elements and major oxides, $\mathrm{pH}$, electrical conductivity (EC), point of zero charge $\left(\mathrm{pH}_{\mathrm{PzC}}\right)$, cation exchange capaci- ty (CEC), zeta potential, bulk density, specific surface area, as well as determination of surface functional groups. The pyrolysis yields were calculated as well, by taking into consideration the initial mass of feedstock and the final mass of carbonaceous material obtained at the end of pyrolysis. Moreover, all biochars were used in germination assays, with Lepidium sativum as a test plant.

Waste biomass feedstocks were also characterized, albeit focusing on proximate and ultimate analyses, $\mathrm{pH}$ and EC determination, as well as compositional analysis regarding mineral elements.

\subsubsection{Proximate and ultimate analyses}

Proximate analysis of biochars was carried out on the basis of ASTM method D1762-84, while for biomass feedstocks APHA (American Public Health Association) method 2540G and ASTM method E897-88 were used. Ultimate analysis was determined by flash combustion at $1,020^{\circ} \mathrm{C}$ using a EuroVector EA300 series elemental analyzer.

\subsection{2 $\mathrm{pH}, E C, \mathrm{pH} \mathrm{PZC}_{\mathrm{C}} \mathrm{CEC}$, zeta potential}

$\mathrm{pH}$ and $\mathrm{EC}$ were measured in the slurry obtained after agitating the materials with the respective liquid media. In the case of biochars, the materials were agitated both in deionized water (for $\mathrm{pH}$ and $\mathrm{EC}$ ) and in $\mathrm{KCl}(1 \mathrm{~N})$ (only for $\mathrm{pH}$ ), with a solid/liquid ratio of $1 / 20 \mathrm{~g} / \mathrm{mL}$ for $1.5 \mathrm{~h}$ (Rajkovich et al., 2012). For the biomass agitation took place in deionized water with a solid/liquid ratio of $1 / 10 \mathrm{~g} / \mathrm{mL}$ for $24 \mathrm{~h}$. In order to determine the $\mathrm{pH}_{\mathrm{PzC}}$ of the different biochars, the $\mathrm{pH}$ 'drift' method was adopted, as reported by Uchimiya et al. (2011). On the other hand, CEC was determined according to EPA method 9081 using sodium acetate and ammonium acetate (EPA, 1986). Zeta potential was measured following the methodology reported by Yao et al. (2011). The measurements were conducted by using a Zetasizer Nano-ZS (Malvern Instruments).

\subsubsection{Bulk density and specific surface area}

Bulk density was determined according to the method reported by Ahmedna et al. (1997), while the specific surface area of carbonaceous materials was determined

TABLE 1: Biochar codification.

\begin{tabular}{|c|c|c|}
\hline Feedstock & Pyrolysis temperature $\left({ }^{\circ} \mathrm{C}\right)$ & Biochar coded name \\
\hline \multirow[t]{2}{*}{ SSC } & 400 & SSC400 \\
\hline & 600 & SSC600 \\
\hline \multirow[t]{2}{*}{ SSP } & 400 & SSP400 \\
\hline & 600 & SSP600 \\
\hline \multirow[t]{2}{*}{ OFMSW } & 400 & OFMSW400 \\
\hline & 600 & OFMSW600 \\
\hline \multirow[t]{2}{*}{ GP } & 400 & GP400 \\
\hline & 600 & GP600 \\
\hline \multirow[t]{2}{*}{$\mathrm{RH}$} & 400 & $\mathrm{RH} 400$ \\
\hline & 600 & $\mathrm{RH} 600$ \\
\hline \multirow[t]{2}{*}{ EOP } & 400 & EOP400 \\
\hline & 600 & EOP600 \\
\hline
\end{tabular}


using a Nicolet 380 (Thermo), after degassing all samples at $200^{\circ} \mathrm{C}$

\subsubsection{Mineral elements and major oxides contents}

Mineral element contents of the produced carbonaceous materials and their precursors were determined via Inductively Coupled Plasma Mass Spectrometry (ICP-MS) (CX 7500, Agilent) after sample acid digestion with $\mathrm{HNO}_{3}$. On the other hand, major oxides contents were determined via Energy Dispersive X-ray fluorescence (XRF) (S2 Ranger, Bruker) after fusion (Claisse Fluxer M4) of ignited $\left(1,050^{\circ} \mathrm{C}\right.$ ) biochar samples (ash samples) with Li-tetraborate.

\subsubsection{Surface functional groups}

The presence of surface functional groups on the biochars was evaluated by recording the materials' FT-IR spectra with a Fourier transform infrared spectrometer (Perkin Elmer Spectrum 1000) using the $\mathrm{KBr}$ pellet technique (sample: $\mathrm{KBr}=1: 100)$.

\subsubsection{Germination assays}

Germination assays were conducted in order to assess the eventual phytotoxic effect of the investigated biochars on Lepidium sativum seed germination and early seedling growth in terms of root elongation. In order to conduct the assays, the twelve biochars were mixed at a $1 \%$ rate, on dry basis, with Phytotoxkit ${ }^{\mathrm{TM}}$ (MicroBioTests Inc.) reference soil ( $85 \%$ sand, $10 \%$ kaolin and $5 \%$ peat, according to the supplier). The amendment rate value (1\%) was selected as a representative intermediate value that would provide an indication of the potential effects, either positive or negative, that the investigated biochars may have on higher plants. Briefly, equal quantities of each soil-biochar mixture were placed in circular Petri dishes (90 mm diameter) and wetted with a quantity of deionized water equivalent to $80 \%$ of the water holding capacity of the soil (Mumme et al., 2018). The same procedure was also followed using the reference soil with no amendments (Control assay). Afterwards, a piece of filter paper, which was also wetted to $80 \%$ of its water holding capacity, was placed inside each dish, on top of the soil mixtures and 10 seeds of Lepidium sativum were arranged in line on the filter paper, at a distance of at least $1 \mathrm{~cm}$ from the edge of the dish. Finally, both test (soil-biochar mixtures) and control dishes were covered with their lids and placed inside an incubation chamber set at $25^{\circ} \mathrm{C}$ at a $50-60^{\circ}$ angle. After $3 \mathrm{~d}$, digital images of the dishes were acquired and root lengths were determined through image analysis, using the ImageJ software. All assays were conducted in triplicates.

In order to evaluate the results, two parameters, i.e. the Germination Index (GI) and the Root Growth Inhibition (RGI), were calculated, according to literature (Nieto et al., 2016; Oleszczuk and Hollert, 2011):

$G I=G \cdot\left(R L_{t} / R L_{c}\right)$

$R G I=\left(R L_{c}-R L_{t}\right) / R L_{c}$

where $\mathrm{G}$ is the percentage of seeds germinated in the test assays (germination rate), $\mathrm{RL}_{\mathrm{t}}$ is the mean root length of the seeds germinated in the test assays, and $\mathrm{RL}_{c}$ is the mean root length of the seeds germinated in the control assays.

\section{RESULTS AND DISCUSSION}

\subsection{Yield and proximate analysis}

As shown in Figure 1 the pyrolysis yield was negatively correlated with the increase in pyrolysis temperature. In fact, while the yield obtained at $400^{\circ} \mathrm{C}$ ranged between 30.4 and $54.9 \%$, the yield obtained at $600^{\circ} \mathrm{C}$ varied from 26.3 to $46.2 \%$. Moreover, when comparing different feedstocks, higher yields and thus higher biochar quantities were obtained from the two sewage sludge types, SSC and SSP, followed by OFMSW, RH and GP. The lowest yields were associated with EOP pyrolysis.

Proximate analysis (Figure 2) showed that the carbonaceous materials produced at $400^{\circ} \mathrm{C}$ contained less ash and more volatile matter, as compared to those produced at $600^{\circ} \mathrm{C}$. As far as the FC contents are concerned, the results depended on the material origin. For biochars obtained from feedstocks of municipal origin, FC appeared to be decreasing as a function of pyrolysis temperature, while the opposite was observed for biochars obtained from feedstocks of agroindustrial origin.

The decrease in pyrolysis yield with increasing temperature has been associated with decomposition of organic matter, as well as with dehydration of hydroxyl groups (Rehrah et al., 2016; Stefaniuk and Oleszczuk, 2015). This phenomenon was corroborated by the analogous reduction in VM contents (Zhao et al., 2017), which in turn resulted in an increase in the concentration of inorganic matter (Suliman et al., 2016; Tag et al., 2016; Zhao et al., 2017) and thus, in increased ash content. As far as FC is concerned, the trends observed in the present study, i.e. both increasing and decreasing trends as a function of temperature, has also been reported by other authors (Ahmad et al., 2012; Ahmad et al., 2014; Gómez et al., 2016; Hossain et al., 2011; Jin et al., 2014; Pellera and Gidarakos, 2015; Rajkovich et al., 2012; Suliman et al., 2016; Taherymoosavi et al., 2017; Zhao et al., 2017), and they may be associated with the ash content of the investigated materials. In fact, Enders et al. (2012) noticed that for materials with ash content above $20 \%$, FC decreased as a function of pyrolysis temperature, while the opposite happens for materials with ash contents below $20 \%$. These authors attributed this phenomenon to

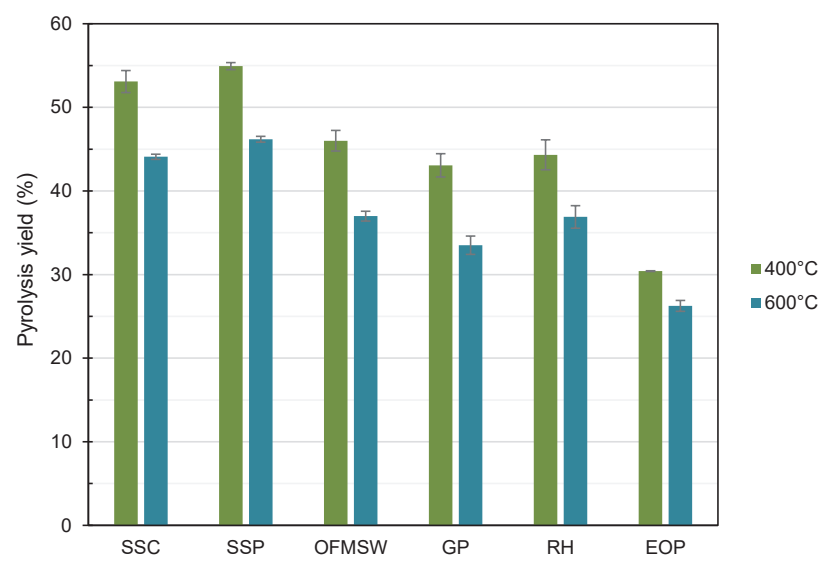

FIGURE 1: Pyrolysis yields for the six feedstocks at two temperatures (error bars represent standard deviation). 
interactions between organic and inorganic constituents of the pyrolyzed materials during thermal treatment (Enders et al., 2012).

As far as the influence of feedstock type is concerned, the ash and VM contents of the six feedstocks exerted a significant effect both on the pyrolysis yield and on the proximate composition of the resulting biochars. In fact, pyrolyzing the material with the highest ash content, i.e. SSP, yielded not only a higher amount of biochar, but also higher-ash-containing materials. Such a relation between yield and ash content was highlighted also in previous studies (Song and Guo, 2012; Suliman et al., 2016).

\subsection{Ultimate analysis}

Ultimate analysis results (Table 2) demonstrated that feedstock origin played an important role in biochar composition. This was particularly evident when observing the biochar $\mathrm{C}$ content. Indeed, while biochars of municipal origin were characterized by $\mathrm{C}$ content ranging from 25.9 to $39.5 \%$, for biochars of agroindustrial origin a much higher range of values was noticed, from 42.2 to $93.7 \%$. $\mathrm{H}$ and $\mathrm{N}$ contents also presented differences in their range of values for different materials, with biochars of agroindustrial origin being characterized by generally lower values. As far as the influence of pyrolysis temperature is concerned, higher temperatures seemed to be generally associated with lower $\mathrm{H}$ and $\mathrm{N}$ contents, while in the case of $\mathrm{C}$, reduced and increased values were observed for materials of municipal and agroindustrial origin, respectively.

The decrease in $\mathrm{H}$ and $\mathrm{O}$ contents with increasing pyrolysis temperature is quite common in the literature and is usually attributed to breakage of weak bonds in the biochar structure (Al-Wabel et al., 2013; Rehrah et al., 2016). As far as the $\mathrm{C}$ content is concerned, the most commonly observed behavior is its increase as a function of temperature (Colantoni et al., 2016; Gómez et al., 2016; Ibn Ferjani et al., 2019; Tag et al., 2016) and it is usually an indication of an intensified carbonization (Rehrah et al., 2016). On the other hand, $\mathrm{C}$ loss has also been reported (Cao and Harris, 2010; Kah et al., 2016; Lu et al., 2013). This phenomenon can most likely be associated with the composition of the biomass feedstocks being used, and particularly with their relatively high ash content, as was also concluded by Kah et al. (2016).

The ratios $\mathrm{H}: \mathrm{C}$ and $\mathrm{O}: \mathrm{C}$ are often used in order to determine the degree of aromaticity and polarity of biochars, respectively, with lower $\mathrm{H}: \mathrm{C}$ ratios characterizing more aromatic materials and lower O:C ratios characterizing less hydrophilic materials (Ahmad et al., 2012; Rehrah et al., 2016). As it is observed in the Van Krevelen diagram (Figure 3), in this study both ratios decreased with increasing pyrolysis temperature, a behavior that has previously been associated with the occurrence of dehydration reactions during pyrolysis, as well as with a higher degree of carbonization for the obtained materials (Rehrah et al., 2016; Tag et al., 2016; Zhao et al., 2017). The highest H:C and $\mathrm{O}: \mathrm{C}$ values were observed for biochars produced from the two sewage sludge feedstocks, i.e. SSC and SSP, at $400^{\circ} \mathrm{C}$. Such elevated values may be attributed to the existence of residual organic material in the biochar (Ahmad et al., 2012; Rehrah et al., 2016). Moreover, the lower $\mathrm{H}: \mathrm{C}$ values of biochars produced at $600^{\circ} \mathrm{C}$ suggest higher aromaticity, thus higher recalcitrance for these materials, while higher O:C values of biochars produced at $400^{\circ} \mathrm{C}$ indicate lower hydrophobicity, which could result in a higher water retention ability (Rehrah et al., 2016). Apart from the two abovementioned ratios, $(\mathrm{O}+\mathrm{N}): \mathrm{C}$ is also used as a polarity index (Ahmad et al., 2012; Oh et al., 2012). This ratio presented a generally decreasing trend with pyrolysis temperature (Table 2), indicating a progressive loss of polar surface functional groups (Ahmad et al., 2012).

\section{$3.3 \mathrm{pH}, \mathrm{EC}, \mathrm{pH}_{\mathrm{PZC}}, \mathrm{CEC}$, zeta potential}

Pyrolysis resulted in materials with higher $\mathrm{pH}$ values (Table 4) compared with their respective precursors (Table 3), while biochar $\mathrm{pH}$ also increased with increasing

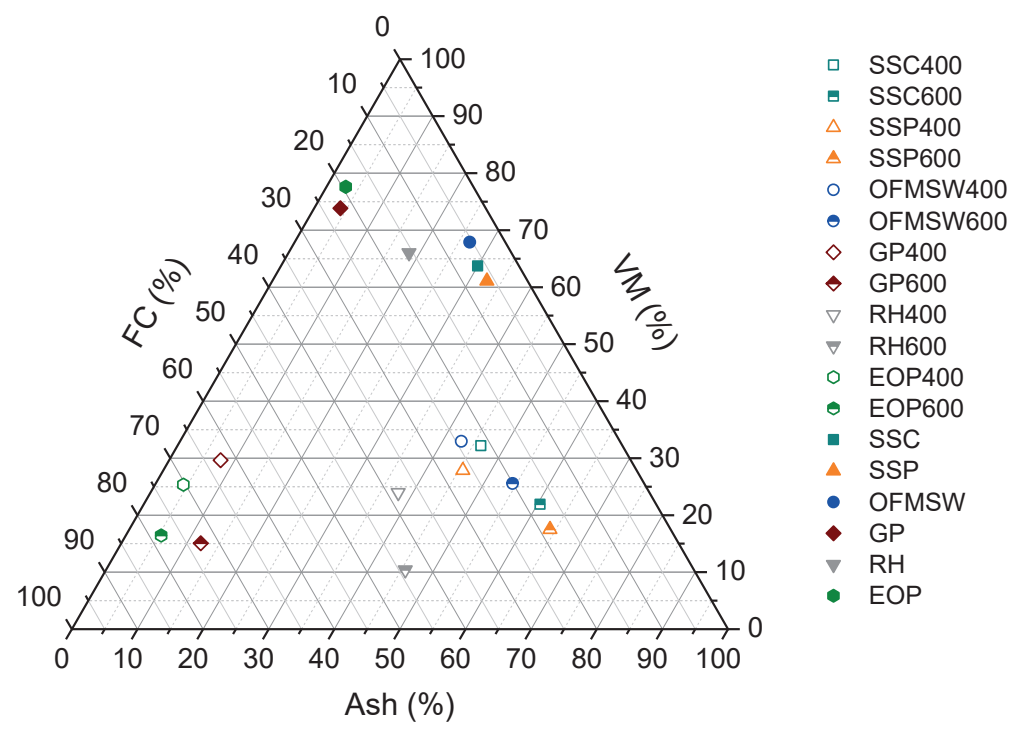

FIGURE 2: Proximate analysis of feedstocks and biochars. 
TABLE 2: Ultimate analysis of feedstocks and biochars, on a dry basis.

\begin{tabular}{|c|c|c|c|c|c|c|c|c|c|c|c|c|c|c|c|c|c|c|c|c|c|c|c|c|c|c|c|}
\hline \multirow{3}{*}{$\begin{array}{l}\text { Element } \\
\mathrm{C}(\%)\end{array}$} & \multicolumn{9}{|c|}{ Municipal feedstocks } & \multicolumn{18}{|c|}{ Biochars } \\
\hline & \multicolumn{3}{|c|}{ ssc } & \multicolumn{3}{|c|}{ SSP } & \multicolumn{3}{|c|}{ OFMSW } & \multicolumn{3}{|c|}{ SSC400 } & \multicolumn{3}{|c|}{ SSC600 } & \multicolumn{3}{|c|}{ SSP400 } & \multicolumn{3}{|c|}{ SSP600 } & \multicolumn{3}{|c|}{ OFMSW400 } & \multicolumn{3}{|c|}{ OFMSW600 } \\
\hline & 35.8 & \pm & 0.0 & 36.4 & \pm & 0.5 & 37.3 & \pm & 0.3 & 29.3 & \pm & 0.8 & 27.5 & \pm & 0.3 & 27.3 & \pm & 0.2 & 25.9 & \pm & 0.4 & 39.5 & \pm & 1.8 & 30.3 & \pm & 0.8 \\
\hline $\mathrm{H}(\%)$ & 11.9 & \pm & 0.0 & 12.4 & \pm & 0.3 & 9.33 & \pm & 0.25 & 3.01 & \pm & 0.99 & 1.88 & \pm & 0.03 & 2.77 & \pm & 0.18 & 0.56 & \pm & 0.09 & 2.06 & \pm & 0.02 & 0.75 & \pm & 0.03 \\
\hline $\mathrm{N}(\%)$ & 4.84 & \pm & 0.38 & 4.71 & \pm & 0.10 & 1.49 & \pm & 0.06 & 3.64 & \pm & 0.14 & 2.57 & \pm & 0.11 & 3.07 & \pm & 0.11 & 2.23 & \pm & 0.22 & 1.57 & \pm & 0.08 & 1.13 & \pm & 0.05 \\
\hline $\mathrm{S}(\%)$ & $<\mathrm{DL}$ & & & $<\mathrm{DL}$ & & & $<D L$ & & & $<\mathrm{DL}$ & & & $<\mathrm{DL}$ & & & $<\mathrm{DL}$ & & & $<\mathrm{DL}$ & & & $<\mathrm{DL}$ & & & $<0.4$ & & \\
\hline $0 *(\%)$ & 17.4 & \pm & 0.4 & 13.8 & \pm & 0.3 & 25.2 & \pm & 0.4 & 17.8 & \pm & 1.4 & 7.65 & \pm & 0.38 & 21.1 & \pm & 0.4 & 7.15 & \pm & 0.32 & 14.0 & \pm & 1.8 & 13.0 & \pm & 0.9 \\
\hline $\mathrm{H}: \mathrm{C}$ & 3.98 & \pm & 0.01 & 2.50 & \pm & 0.01 & 3.01 & \pm & 0.08 & 1.24 & \pm & 0.40 & 0.82 & \pm & 0.02 & 1.22 & \pm & 0.08 & 0.26 & \pm & 0.05 & 0.63 & \pm & 0.03 & 0.30 & \pm & 0.00 \\
\hline O:C & 0.36 & \pm & 0.01 & 0.22 & \pm & 0.00 & 0.51 & \pm & 0.01 & 0.46 & \pm & 0.05 & 0.21 & \pm & 0.01 & 0.58 & \pm & 0.01 & 0.21 & \pm & 0.01 & 0.27 & \pm & 0.05 & 0.32 & \pm & 0.03 \\
\hline$(0+N): C$ & 0.48 & \pm & 0.00 & 0.39 & \pm & 0.01 & 0.54 & \pm & 0.01 & 0.56 & \pm & 0.05 & 0.29 & \pm & 0.01 & 0.68 & \pm & 0.01 & 0.28 & \pm & 0.01 & 0.30 & \pm & 0.05 & 0.35 & \pm & 0.03 \\
\hline \multirow{2}{*}{ Element } & \multicolumn{9}{|c|}{ Agroindustrial feedstocks } & \multicolumn{18}{|c|}{ Biochars } \\
\hline & \multicolumn{3}{|c|}{ GP } & \multicolumn{3}{|c|}{ RH } & \multicolumn{3}{|c|}{ EOP } & \multicolumn{3}{|c|}{ GP400 } & \multicolumn{3}{|c|}{ GP600 } & \multicolumn{3}{|c|}{ RH400 } & \multicolumn{3}{|c|}{ RH600 } & \multicolumn{3}{|c|}{ EOP400 } & \multicolumn{3}{|c|}{ EOP600 } \\
\hline C (\%) & 48.1 & \pm & 0.7 & 40.0 & \pm & 0.6 & 47.3 & \pm & 0.2 & 69.1 & \pm & 5.3 & 83.9 & \pm & 1.3 & 42.2 & \pm & 1.2 & 43.4 & \pm & 1.8 & 83.2 & \pm & 0.9 & 93.7 & \pm & 0.4 \\
\hline $\mathrm{H}(\%)$ & 9.23 & \pm & 0.56 & 8.62 & \pm & 0.13 & 9.84 & \pm & 0.06 & 5.34 & \pm & 0.08 & 2.17 & \pm & 0.19 & 2.05 & \pm & 0.10 & 1.19 & \pm & 0.02 & 1.84 & \pm & 0.90 & 1.32 & \pm & 0.13 \\
\hline$N(\%)$ & 2.53 & \pm & 0.20 & 0.54 & \pm & 0.06 & 1.00 & \pm & 0.19 & 2.82 & \pm & 0.57 & 0.71 & \pm & 0.12 & 0.38 & \pm & 0.02 & 0.27 & \pm & 0.03 & 0.02 & \pm & 0.00 & $<\mathrm{DL}$ & & \\
\hline $\mathrm{S}(\%)$ & $<\mathrm{DL}$ & & & $<\mathrm{DL}$ & & & $<\mathrm{DL}$ & & & $<\mathrm{DL}$ & & & $<\mathrm{DL}$ & & & $<\mathrm{DL}$ & & & $<\mathrm{DL}$ & & & $<\mathrm{DL}$ & & & $<\mathrm{DL}$ & & \\
\hline $0 *(\%)$ & 36.2 & \pm & 0.6 & 32.5 & \pm & 0.5 & 38.9 & \pm & 0.3 & 14.9 & \pm & 4.8 & 1.10 & \pm & 1.06 & 17.6 & \pm & 1.3 & 9.54 & \pm & 1.78 & 10.6 & \pm & 1.0 & $<0.1$ & & \\
\hline $\mathrm{H}: \mathrm{C}$ & 2.30 & \pm & 0.16 & 2.59 & \pm & 0.06 & 2.50 & \pm & 0.01 & 0.93 & \pm & 0.06 & 0.31 & \pm & 0.03 & 0.58 & \pm & 0.02 & 0.33 & \pm & 0.02 & 0.27 & \pm & 0.13 & 0.17 & \pm & 0.02 \\
\hline O:C & 0.56 & \pm & 0.01 & 0.61 & \pm & 0.02 & 0.62 & \pm & 0.01 & 0.16 & \pm & 0.06 & 0.01 & \pm & 0.01 & 0.31 & \pm & 0.03 & 0.17 & \pm & 0.04 & 0.10 & \pm & 0.01 & 0.00 & \pm & 0.00 \\
\hline$(\mathrm{O}+\mathrm{N}): \mathrm{C}$ & 0.61 & \pm & 0.01 & 0.62 & \pm & 0.02 & 0.64 & \pm & 0.01 & 0.20 & \pm & 0.07 & 0.02 & \pm & 0.01 & 0.32 & \pm & 0.03 & 0.17 & \pm & 0.04 & 0.10 & \pm & 0.01 & $<0.01$ & & \\
\hline
\end{tabular}

$D L$ : Detection Limit , * determined by difference, values are expressed as average \pm standard deviation

production temperature. This behavior may be attributed to phenomena occurring during pyrolysis, such as the progressive loss of acidic functional groups from the materials surface (Mukherjee et al., 2011; Stefaniuk and Oleszczuk, 2015), as well as the separation of alkali salts from the materials organic matrices (Al-Wabel et al., 2013). It has also been previously associated with the increase in ash content of the biochars during pyrolysis (Rehrah et al., 2016; Tag et al., 2016). According to the obtained data all tested carbonaceous materials can be characterized as alkaline, with biochars of agroindustrial origin generally showing higher values, with the exception of $\mathrm{RH} 400$, which not only was associated with the lowest $\mathrm{pH}$ values among all materials, but it was also characterized as acidic.

In terms of $\mathrm{pH}_{\mathrm{PZC}^{\prime}}$ the results were consistent with $\mathrm{pH}$ data, with values being lower compared with the respective $\mathrm{pH}$ values. The differences were more significant for biochars of agroindustrial origin. On the contrary, CEC of the tested materials decreased with increasing production temperature. CEC presented relatively high values ranging from 119 to $494 \mathrm{meq} / \mathrm{kg}$. This behavior for both parame-

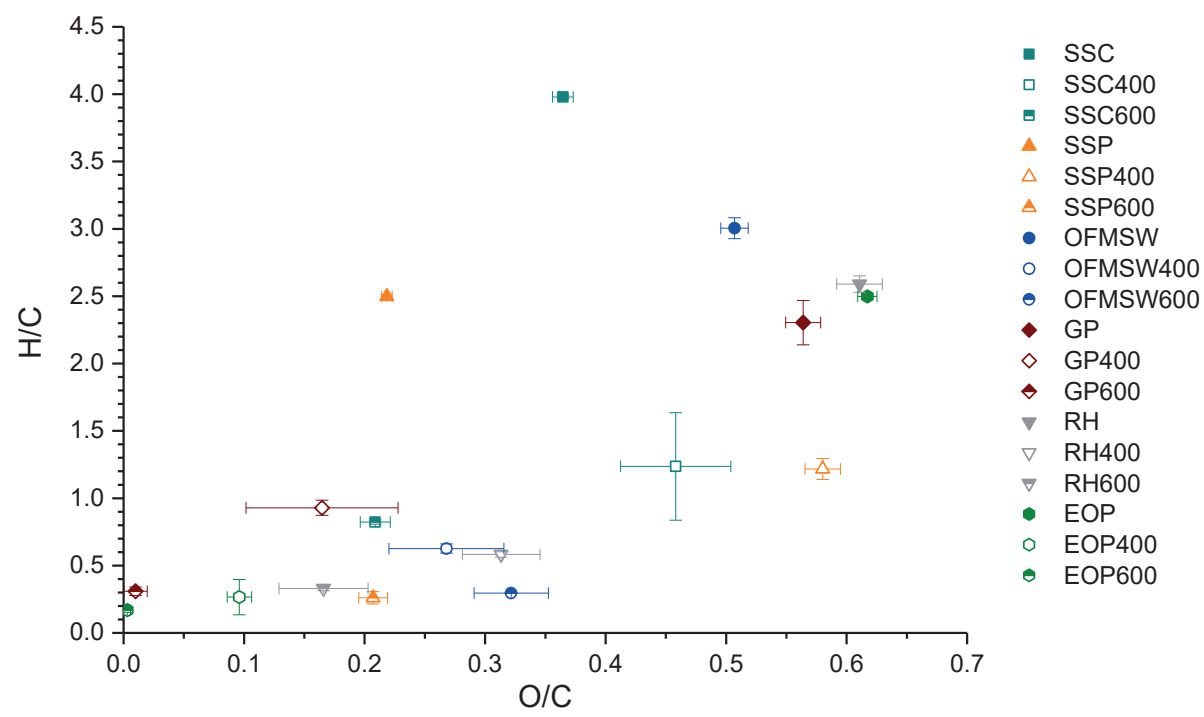

FIGURE 3: van Krevelen diagram (error bars represent standard deviation). 
ters was a consequence of the intensified removal of surface functional groups at higher pyrolysis temperatures (Inguanzo et al., 2002; Lu et al., 2013; Suliman et al., 2016; Tag et al., 2016; Zhao et al., 2017).

In the case of EC, its variation as a function of pyrolysis temperature followed a different behavior for materials of different origin (Table 4). Specifically, for biochars of municipal origin a decrease was observed, while for those of agroindustrial origin the values were found to increase. Most studies refer to a positive correlation between EC, $\mathrm{pH}$ and ash contents (Rehrah et al., 2016; Song and Guo, 2012), which in turn comes as a result of volatile material loss (Stefaniuk and Oleszczuk, 2015); however an opposite behavior has also been observed in previous studies (Hossain et al., 2011; Luo et al., 2014; Manolikaki et al., 2016; Oh et al., 2012). In addition, biochar EC values were lower compared with those of their respective precursors (Table 3).

EC is often used to estimate salinity and as an index for evaluating the quality of fertilizers. More specifically, if a biochar is characterized by high salinity, it is usually not rec- ommended for soil applications, due to potential harmful effects on plants, while very low salinity is also undesirable (Tag et al., 2016). According to a classification reported by Belyaeva et al. (2012), materials with EC values (determined with a 1:5 soil:water ratio) between 500 and 1500 $\mu \mathrm{S} / \mathrm{cm}$ are considered moderately saline, those in the range $1500-2000 \mu \mathrm{S} / \mathrm{cm}$, extremely saline, while those above $2000 \mu \mathrm{S} / \mathrm{cm}$, too saline for most plants. Assuming that the dilution factor between the above mentioned ratio and the one used in the present study (1:20) applies for EC values (Singh et al., 2017), most biochars might be characterized as moderately saline, whereas SSC400, GP400 and GP600 as extremely saline, and OFMSW400 and OFMSW600 as too saline for most plants.

As far as zeta potential is concerned, negative values for all biochars revealed the negative surface charge of the materials (Yargicoglu et al., 2015), while the increasing electronegativity with increasing pyrolysis temperature is in agreement with previous results (Mukherjee et al., 2011).

TABLE 3: pH and EC of feedstocks.

\begin{tabular}{|c|c|c|c|c|c|c|c|c|c|c|c|c|c|c|c|c|c|c|}
\hline \multirow{3}{*}{$\begin{array}{l}\text { Properties } \\
\mathrm{pH}\end{array}$} & \multicolumn{9}{|c|}{ Municipal feedstocks } & \multicolumn{9}{|c|}{ Agroindustrial feedstocks } \\
\hline & \multicolumn{3}{|c|}{ ssc } & \multicolumn{3}{|c|}{ SSP } & \multicolumn{3}{|c|}{ OFMSW } & \multicolumn{3}{|c|}{ GP } & \multicolumn{3}{|c|}{$\mathbf{R H}$} & \multicolumn{3}{|c|}{ EOP } \\
\hline & 7.09 & \pm & 0.03 & 7.10 & \pm & 0.08 & 6.11 & \pm & 0.04 & 3.82 & \pm & 0.06 & 5.91 & \pm & 0.02 & 5.50 & \pm & 0.23 \\
\hline $\mathrm{EC}(\mathrm{mS} / \mathrm{cm})$ & 2.00 & \pm & 0.01 & 2.18 & \pm & 0.06 & 7.95 & \pm & 0.12 & 2.53 & \pm & 0.02 & 0.79 & \pm & 0.01 & 2.01 & \pm & 0.04 \\
\hline
\end{tabular}

TABLE 4: Chemical and physical properties of biochars.

\begin{tabular}{|c|c|c|c|c|c|c|c|c|c|c|c|c|c|c|c|c|c|c|}
\hline \multirow{3}{*}{$\begin{array}{l}\text { Properties } \\
\text { Chemical properties }\end{array}$} & \multicolumn{18}{|c|}{ Biochars of municipal origin } \\
\hline & \multicolumn{3}{|c|}{ SSC400 } & \multicolumn{3}{|c|}{ SSC600 } & \multicolumn{3}{|c|}{ SSP400 } & \multicolumn{3}{|c|}{ SSP600 } & \multicolumn{3}{|c|}{ OFMSW400 } & \multicolumn{3}{|c|}{ OFMSW600 } \\
\hline & & & & & & & & & & & & & & & & & & \\
\hline $\mathrm{pH}(\mathrm{DW})$ & 7.53 & \pm & 0.04 & 7.45 & \pm & 0.04 & 7.94 & \pm & 0.05 & 8.63 & \pm & 0.06 & 8.50 & \pm & 0.06 & 9.76 & \pm & 0.04 \\
\hline $\mathrm{pH}(\mathrm{KCl})$ & 7.40 & \pm & 0.05 & 7.43 & \pm & 0.02 & 7.27 & \pm & 0.01 & 8.05 & \pm & 0.01 & 8.38 & \pm & 0.03 & 9.50 & \pm & 0.04 \\
\hline $\mathrm{pH}_{\mathrm{PZC}}$ & 7.14 & \pm & 0.05 & 7.20 & \pm & 0.05 & 7.11 & \pm & 0.05 & 7.41 & \pm & 0.05 & 8.30 & \pm & 0.05 & 9.47 & \pm & 0.05 \\
\hline $\mathrm{EC}(\mu \mathrm{S} / \mathrm{cm})$ & 429 & \pm & 7 & 326 & \pm & 12 & 333 & \pm & 9 & 199 & \pm & 2 & 1785 & \pm & 80 & 871 & \pm & 7 \\
\hline CEC (meq/kg) & 176 & \pm & 1 & 126 & \pm & 2 & 371 & \pm & 2 & 180 & \pm & 2 & 388 & \pm & 17 & 257 & \pm & 10 \\
\hline Zeta potential $(\mathrm{mV})$ & -9.84 & \pm & 1.24 & -11.5 & \pm & 1.8 & -10.2 & \pm & 2.8 & -11.9 & \pm & 1.7 & -9.97 & \pm & 1.93 & -13.8 & \pm & 2.9 \\
\hline \multicolumn{19}{|l|}{ Physical properties } \\
\hline Specific surface area $\left(\mathrm{m}^{2} / \mathrm{g}\right)$ & 2.87 & \pm & 0.03 & 23.8 & \pm & 3.4 & 14.4 & \pm & 0.1 & 52.5 & \pm & 5.9 & 8.03 & \pm & 0.82 & 101 & \pm & 4 \\
\hline Bulk density $\left(\mathrm{kg} / \mathrm{m}^{3}\right)$ & 711 & \pm & 12 & 945 & \pm & 11 & 652 & \pm & 9 & 751 & \pm & 3 & 400 & \pm & 2 & 464 & \pm & 0 \\
\hline \multirow{2}{*}{ Properties } & \multicolumn{18}{|c|}{ Biochars of agroindustrial origin } \\
\hline & \multicolumn{3}{|c|}{ GP400 } & \multicolumn{3}{|c|}{ GP600 } & \multicolumn{3}{|c|}{ RH400 } & \multicolumn{3}{|c|}{ RH600 } & \multicolumn{3}{|c|}{ EOP400* } & \multicolumn{3}{|c|}{ EOP600* } \\
\hline \multicolumn{19}{|l|}{ Chemical properties } \\
\hline $\mathrm{pH}(\mathrm{DW})$ & 9.05 & \pm & 0.04 & 9.93 & \pm & 0.22 & 6.49 & \pm & 0.06 & 9.23 & \pm & 0.03 & 9.52 & \pm & 0.16 & 10.05 & \pm & 0.04 \\
\hline $\mathrm{pH}(\mathrm{KCl})$ & 7.76 & \pm & 0.04 & 9.23 & \pm & 0.10 & 4.44 & \pm & 0.03 & 7.36 & \pm & 0.06 & 8.02 & \pm & 0.27 & 9.03 & \pm & 0.06 \\
\hline $\mathrm{pH}_{\mathrm{PZC}}$ & 7.45 & \pm & 0.05 & 8.14 & \pm & 0.05 & 6.33 & \pm & 0.05 & 7.72 & \pm & 0.05 & 7.32 & \pm & 0.05 & 7.75 & \pm & 0.05 \\
\hline $\mathrm{EC}(\mu \mathrm{S} / \mathrm{cm})$ & 422.7 & \pm & 26.2 & 468.0 & \pm & 55.7 & 179.6 & \pm & 3.2 & 190.5 & \pm & 3.7 & 267.3 & \pm & 7.8 & 341.3 & \pm & 7.4 \\
\hline CEC (meq/kg) & 196 & \pm & 28 & 134 & \pm & 3 & 494 & \pm & 25 & 212 & \pm & 2 & 203 & \pm & 4 & 119 & \pm & 2 \\
\hline Zeta potential $(\mathrm{mV})$ & -20.4 & \pm & 1.3 & -19.3 & \pm & 1.7 & -12.2 & \pm & 0.4 & -13.4 & \pm & 1.1 & -11.2 & \pm & 1.5 & -15.7 & \pm & 2.7 \\
\hline \multicolumn{19}{|l|}{ Physical properties } \\
\hline Specific surface area $\left(\mathrm{m}^{2} / \mathrm{g}\right)$ & 1.29 & \pm & 0.05 & 21.8 & \pm & 5.4 & 59.4 & \pm & 2.3 & 215 & \pm & 7 & 6.85 & \pm & 2.76 & 128 & \pm & 7 \\
\hline Bulk density $\left(\mathrm{kg} / \mathrm{m}^{3}\right)$ & 515 & \pm & 22 & 516 & \pm & 12 & 303 & \pm & 27 & 312 & \pm & 11 & 357 & \pm & 23 & 365 & \pm & 29 \\
\hline
\end{tabular}

* these materials were analysed in particle form in all cases except specific surface area analysis (materials ground in mortar), values are expressed as average \pm standard deviation 


\subsection{Specific surface area and bulk density}

In terms of physical characteristics (Table 4), specific surface area and bulk density, a positive effect of pyrolysis temperature on these two parameters was observed. Increased surface area for biochars produced at $600^{\circ} \mathrm{C}$ is in agreement with the findings of other authors (Cao and Harris, 2010; Randolph et al., 2017) and is most likely a result of the progressive decomposition of organic matter and the more intense formation of micropores and channels within the structure of the biochars (Ahmad et al., 2012; Zhao et al., 2017). However, in the present study, the differences between lower- and higher-temperature biochars were very pronounced, or in other words, the specific surface areas of all materials produced at $400^{\circ} \mathrm{C}$ were comparatively quite low. Such a phenomenon has been previously reported in the literature and has been associated with partial blockage of pores by condensed volatile materials (tars), inorganic compounds (ash), and/or other amorphous decomposition products (Rehrah et al., 2014).

As far as bulk density is concerned, this parameter is often determined for biochar materials, especially when they are intended for soil applications, since it affects soil quality, particularly in terms of porosity and compaction (Rehrah et al., 2016). In this study there was a positive relation between bulk density and pyrolysis temperature, in agreement with Rajkovich et al. (2012) and Rehrah et al. (2016).

\subsection{Mineral elements contents}

Table 5 presents the results regarding the mineral elements content of the twelve biochars, obtained after acid digestion. Generally, biochars of municipal origin were richer in mineral elements compared with biochars of agroindustrial origin, with total concentrations ranging at levels of approximately $47-91 \mathrm{~g} / \mathrm{kg}$ and $3.4-20 \mathrm{~g} / \mathrm{kg}$, respectively. For the former biochars, the most abundant element was $\mathrm{Ca}$, with particularly elevated concentrations ranging from $32 \mathrm{~g} / \mathrm{kg}$ (SSC400) to $82 \mathrm{~g} / \mathrm{kg}$ (OFMSW600). Among other elements found also at relatively elevated concentrations, in the region around 1-10 $( \pm 2) \mathrm{g} / \mathrm{kg}$, were, for SS-derived biochars $\mathrm{Fe}, \mathrm{Mg}$ and $\mathrm{Al}$, plus $\mathrm{K}$ and $\mathrm{Na}$ for SSP400 and SSP600, and for OF-derived biochars $\mathrm{Mg}, \mathrm{K}, \mathrm{Na}, \mathrm{Fe}$ and $\mathrm{Al}$. All the other tested elements, including potentially toxic metal(loid)s (PTMs), were found in concentrations not exceeding $0.8 \mathrm{~g} / \mathrm{kg}$ (or even $0.2 \mathrm{~g} / \mathrm{kg}$ in certain cases). Nevertheless, to this regard, the fact that in SS-derived biochars there was a more pronounced presence of $\mathrm{Zn}, \mathrm{Pb}, \mathrm{Cu}, \mathrm{Mn}$ and $\mathrm{Cr}$, compared with OF-derived biochars, is noteworthy. As far as agroindustrial biochars are concerned, the elements with the two highest concentrations were $\mathrm{Ca}$ and $\mathrm{K}$, with the former being the most abundant for GP-derived biochars (max. $\sim 11.6 \mathrm{~g} / \mathrm{kg}$ ), and the latter for $\mathrm{RH}$ - and EOP-derived biochars (max. $\sim 4.6 \mathrm{~g} / \mathrm{kg}$ ). Intermediate concentrations, with values around 0.1-1.2 $( \pm 0.02) \mathrm{g} / \mathrm{kg}$ depending on the material, were measured for elements such as $\mathrm{Mg}, \mathrm{Fe}, \mathrm{Mn}, \mathrm{Al}$ and $\mathrm{Na}$. Finally, in this case, all elements found in lesser quantities reached values below $0.1 \mathrm{~g} / \mathrm{kg}$. It is worth mentioning that the orders of magnitude, as well as rank orders in each case, varied depending on the biochar feedstock.
Regarding the mineral elements detected in more significant amounts, i.e. $\mathrm{Ca}, \mathrm{Fe}, \mathrm{Al}, \mathrm{Mg}, \mathrm{K}, \mathrm{Mn}$ and $\mathrm{Na}$, pyrolysis resulted in increase in their concentrations (Table 5), while further increase in pyrolysis temperature led to mostly increased and mostly decreased concentrations for municipal and agroindustrial biochars, respectively. The results of the present study agree, in general, with similar findings reported elsewhere (Al-Wabel et al., 2013; Cao and Harris, 2010; Hossain et al., 2011; Jin et al., 2014; Lu et al., 2013; Rehrah et al., 2016; Shen et al., 2017; Song and Guo, 2012; Zhao et al., 2017). Regarding PTMs, their values were in general terms comparable to those in the literature (Domene et al., 2015; Jin et al., 2014; Kah et al., 2016; Pituello et al., 2015), while they did not exceed the limit values set by the Council Directive 86/278/EEC on the use of sludge in agriculture (EC, 2009). As far as the effect of pyrolysis temperature on these elements is concerned, their behavior was characterized by high variability, with both increasing and decreasing trends being noticed. This is most likely due to the ability of certain elements to volatilize at high temperatures (Hossain et al., 2011; Li and Jiang, 2017; Luo et al., 2014; Pituello et al., 2015; Zhao et al., 2017).

\subsection{Surface functional groups}

The presence of surface functional groups on biochars was evaluated through the FT-IR spectra illustrated in Figure 4. At first glance, it is evident that there is a high degree of pattern similarity between the spectra of the two sewage sludge-derived biochars, as well as between those of GP- and EOP-derived biochars. Moreover, the spectra of the OFMSW-derived biochars, although presenting bands at similar wavenumbers as the SS-derived biochars, differ in terms of band intensity.

In more detail, biochars of both municipal and agroindustrial origin, all presented distinct bands with highest points in the range $3418-3350 \mathrm{~cm}^{-1}$ and $3442-3328 \mathrm{~cm}^{-1}$, as well as $1616-1558 \mathrm{~cm}^{-1}$ and $1614-1574 \mathrm{~cm}^{-1}$, respectively. The former broad bands indicate the presence of hydrogen bonds and may be assigned to $\mathrm{O}-\mathrm{H}$ stretching (Coates, 2000). As far as the latter bands are concerned, they are usually associated with the presence of aromatic compounds (Coates, 2000) and may be assigned to $C=C$ stretching (Chen et al., 2008) and/or to carboxylate, which is especially likely in the cases of GP400 and EOP400, for which weak peaks at 1384 and $1372 \mathrm{~cm}^{-1}$, respectively, were also observed (Coates, 2000). Moreover, all biochars, except those derived from $\mathrm{RH}$, presented peaks around 1434 and $874 \mathrm{~cm}^{-1}$, which may be assigned to carbonates (Coates, 2000). Specifically in the case of biochars of municipal origin, these peaks combined with weak peaks at $712 \mathrm{~cm}^{-1}$, are consistent with the possible presence of calcite, whose typical peaks are found around 1433, 874 and $713 \mathrm{~cm}^{-1}$ (Jimoh et al., 2017; Nasir et al., 2019). In addition to the above mentioned bands which were common to all biochars, some others were common only among certain materials. Indeed, weak bands with highest points between 2954 and $2864 \mathrm{~cm}-1$, as well as medium to strong peaks between 1046 and $1034 \mathrm{~cm}^{-1}$, were observed only for biochars of municipal origin. The former bands indicate the presence of aliphatic groups, with specific assignments to 
TABLE 5: Mineral element content $(\mathrm{mg} / \mathrm{kg}$ ) of feedstocks and biochars, on a dry basis.

\begin{tabular}{|c|c|c|c|c|c|c|c|c|c|c|c|c|c|c|c|c|c|c|c|c|c|c|c|c|c|c|c|}
\hline \multirow{3}{*}{ 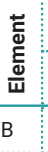 } & \multicolumn{9}{|c|}{ unicipal feedstocks } & \multicolumn{18}{|c|}{ Biochars } \\
\hline & \multicolumn{3}{|c|}{ ssc } & \multicolumn{3}{|c|}{ SSP } & \multicolumn{3}{|c|}{ OFMSW } & \multicolumn{3}{|c|}{ Ssc400 } & \multicolumn{3}{|c|}{ ssc600 } & \multicolumn{3}{|c|}{ SSP400 } & \multicolumn{3}{|c|}{ SSP600 } & \multicolumn{3}{|c|}{ OFMSW400 } & \multicolumn{3}{|c|}{ OFMSW600 } \\
\hline & 7.27 & \pm & 0.09 & 6.91 & \pm & 0.12 & .23 & \pm & 0.43 & 17 & \pm & 1.47 & 8.30 & \pm & 0.33 & 82 & \pm & 0.02 & 24 & \pm & 0.87 & 1.9 & 1 & 4 & 15.7 & \pm & 1.7 \\
\hline $\mathrm{N}$ & 274 & \pm & 28 & 72 & \pm & 9 & 31 & \pm & 8 & 314 & \pm & & 340 & \pm & 8 & 700 & \pm & 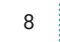 & 0 & \pm & 2 & 044 & \pm & 1 & 236 & + & 9 \\
\hline $\mathrm{Mg}$ & 65 & \pm & 8 & 2521 & \pm & 15 & 2 & \pm & 84 & 73 & \pm & 284 & 30 & \pm & 62 & 38 & \pm & 7 & 423 & \pm & 5 & 49 & \pm & 59 & 496 & \pm & 8 \\
\hline $\mathrm{Al}$ & 80 & \pm & 8 & & \pm & 65 & & :- & 38 & 0 & \pm & 181 & 93 & \pm & 54 & 93 & \pm & 116 & 074 & \pm & 44 & 69 & \pm & 14 & 996 & \pm & 35 \\
\hline K & & \pm & 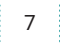 & & $-:$ & 6 & 9 & \pm & 12 & & \pm & & & 4 & 10 & 92 & \pm & 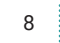 & 181 & \pm & 28 & 788 & \pm & 130 & 890 & \pm & 14 \\
\hline $\mathrm{Ca}$ & 637 & \pm & 360 & 1035 & \pm & 523 & 679 & \pm 4 & 4658 & 123 & \pm & 5619 & 036 & \pm & 1205 & 1945 & \pm & 411 & 5461 & \pm & 6504 & 65207 & \pm & 2162 & 1895 & \pm & 793 \\
\hline $\mathrm{Cr}$ & & \pm & 0.4 & 150 & \pm & 2 & 34 & \pm & 0. & 9 & \pm & 3.1 & 3 & \pm & & 37 & \pm & 5 & 1 & \pm & 15 & 72 & \pm & 0.35 & .13 & \pm & 0.25 \\
\hline $\mathrm{Mn}$ & 6 & \pm & 0. & 5.9 & \pm & 1.8 & 6 & \pm & 10 & 9 & \pm & & & \pm & 3 & 2 & \pm & 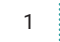 & 07 & \pm & 11 & 5.9 & \pm & 11.2 & 4.0 & \pm & 4.2 \\
\hline $\mathrm{Fe}$ & 987 & \pm & 153 & 2282 & ${ }^{1}$ & 8 & 716 & \pm & 42 & 462 & \pm & 1404 & 521 & \pm & 396 & 862 & \pm & 82 & 027 & \pm & 175 & 05 & \pm & 31 & 1213 & \pm & 133 \\
\hline Co & 0.52 & \pm & 0.00 & 1.02 & \pm & 0.01 & 0.40 & \pm & 0.04 & \multicolumn{3}{|c|}{$<1.37$} & \multicolumn{3}{|c|}{$<1.37$} & & 1.37 & & & 1.36 & & & $<1.36$ & & & 1.37 & \\
\hline $\mathrm{Ni}$ & 7.38 & \pm & 0.15 & 22.4 & \pm & 0.0 & 13.5 & \pm & 15.0 & 5.4 & \pm & 2.4 & 0.1 & \pm & 2 & 1.1 & \pm & 0.7 & 27.7 & \pm & 3.5 & .29 & \pm & 0.53 & .05 & \pm & 0.14 \\
\hline $\mathrm{Cu}$ & 87.1 & \pm & 12.5 & 195 & \pm & 7 & 30.0 & \pm & 3.0 & 94.5 & \pm & 8.9 & 102 & \pm & 2 & 25 & \pm & & 05 & \pm & 17 & 5.1 & \pm & 3 & 59.7 & \pm & 35.5 \\
\hline $\mathrm{Zn}$ & 283 & \pm & 0 & 379 & \pm & 10 & .1 & \pm & 3.7 & 15 & \pm & 6 & 546 & \pm & & 05 & \pm & 2 & 88 & \pm & 63 & 27 & \pm & 4 & 125 & \pm & 0 \\
\hline As & 18 & \pm & 0.01 & 16 & \pm & 0.04 & 0.20 & \pm & 0.06 & 1.17 & \pm & 0.11 & 6 & \pm & 0. & 87 & \pm & 0.03 & 68 & \pm & 0 & 39 & \pm & 001 & .54 & \pm & 0.04 \\
\hline $\mathrm{Se}$ & & 0.33 & & & 0.32 & & & 0.33 & & 0.50 & \pm & 0.22 & & $<0.33$ & & & .33 & & & 0.33 & & & $=0.33$ & & & 0.33 & \\
\hline Mo & 5.07 & \pm & 0.08 & 3.73 & \pm & 0.04 & 91 & \pm & 0.06 & 6.97 & \pm & 0.76 & 6.81 & \pm & 0.13 & .92 & \pm & 0.04 & 4.69 & \pm & 0.44 & 0.89 & \pm & 0.32 & 1.45 & \pm & 0.06 \\
\hline $\mathrm{Cd}$ & 0.28 & \pm & 0.03 & 0.46 & \pm & 0.09 & & 0.030 & & 0.57 & \pm & 0.06 & 0.58 & \pm & 0.06 & 0.89 & \pm & 0.03 & 0.94 & \pm & 0.06 & 0.059 & \pm & 0.005 & 0.060 & \pm & 0.004 \\
\hline $\mathrm{Hg}$ & 1.69 & \pm & 0.05 & 1.45 & \pm & 0.02 & 0.32 & \pm & 0.00 & 0.35 & \pm & 0.07 & 0.32 & \pm & 0.08 & 0.44 & \pm & 0.04 & 0.65 & \pm & 0.14 & 0.34 & \pm & 0.02 & 0.30 & \pm & 0.01 \\
\hline $\mathrm{Pb}$ & 55 & \pm & 0.3 & 74.3 & \pm & 1. & 23 & \pm & 6.4 & 1 & \pm & 13 & 110 & + & 1 & 148 & \pm & 1 & 18 & \pm & 10 & ) & \pm & 30 & 40.4 & \pm & 1 \\
\hline $\overrightarrow{\mathbf{z}}$ & & & & roi & rial $f$ & fee & & & & & & & & & & & & & & & & & & & & & \\
\hline एक & & GF & & & RH & & & EOP & & & P40C & & & P600 & & & -400 & & & 460 & & & OP40 & & & $\mathrm{P} 60$ & \\
\hline B & & \pm & 0.1 & 2.29 & \pm & & & 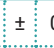 & 0. & & \pm & & & \pm & & 2.69 & \pm & 0 & 2.34 & \pm & & 33 & \pm & 0.12 & 4 & 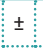 & 07 \\
\hline $\mathrm{Na}$ & 52.5 & \pm & 2 & 54.3 & \pm & 1 & & \pm & & & \pm & & & \pm & & & \pm & 40 & & \pm & & & 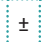 & & & \pm & 1.1 \\
\hline $\mathrm{Mg}$ & & \pm & 20 & 302 & \pm & 77 & & : & & & $I$ & & & \pm & & & 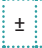 & & & \pm & & & 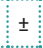 & & & \pm & 3 \\
\hline $\mathrm{Al}$ & & .059 & & 1 & \pm & 1 & & .059 & & & \pm & & & \pm & & & \pm & & & \pm & & & \pm & & 7 & \pm & 26 \\
\hline K & & \pm & 1 & & \pm & 4 & 5 & \pm & 24 & 9 & \pm & 255 & 2 & \pm & & 074 & \pm & 83 & 36 & \pm & & 16 & \pm & & 88 & \pm & 23 \\
\hline $\mathrm{Ca}$ & 5407 & \pm & 1 & & 471 & & & 311 & & 1 & \pm & & 0 & \pm & & & \pm & 265 & & \pm & 97 & 69 & \pm & & & \pm & 8 \\
\hline $\mathrm{Cr}$ & 1.1 & \pm & 1.01 & & \pm & & & \pm & 0. & & \pm & 5 & & \pm & & & \pm & 0.36 & & \pm & 9 & 3 & \pm & 6 & 6 & \pm & 00 \\
\hline $\mathrm{Mn}$ & 62 & \pm & 0.16 & & \pm & & & \pm & 1. & & \pm & & & \pm & & & \pm & & & \pm & & & \pm & & 9 & \pm & 18 \\
\hline $\mathrm{Fe}$ & .4 & \pm & 1 & & \pm & 49 & 3 & \pm & 27 & 14 & \pm & & 3 & \pm & & .5 & \pm & 1.4 & 3 & \pm & & 5.4 & \pm & 3 & 29.5 & \pm & 1.4 \\
\hline Co & & 0.22 & & & 0.21 & & & 0.21 & & & .36 & & & $<1.37$ & & & 1.36 & & & 1.37 & & & $=1.37$ & & & 1.37 & \\
\hline $\mathrm{Ni}$ & 0.24 & \pm & 0.14 & 16 & \pm & 0. & & 0.12 & & 0.57 & \pm & 0.10 & 0.30 & \pm & 0 & 56 & \pm & 0.19 & 2.10 & \pm & 5 & 1.07 & \pm & 0.86 & & 0.082 & \\
\hline $\mathrm{Cu}$ & 30.3 & \pm & 1.2 & 32.4 & \pm & 40.0 & 26.6 & \pm & 33 & 41.2 & \pm & 0.9 & 7.77 & \pm & 1.12 & 4.52 & \pm & 0.03 & 4.60 & \pm & 0.16 & 4.81 & \pm & 0.12 & 6 & \pm & 13 \\
\hline $\mathrm{Zn}$ & 1.9 & \pm & 2.1 & 1 & \pm & 7. & 36 & \pm & 1. & .4 & \pm & 4.3 & 7 & \pm & 3.6 & .8 & \pm & 7.6 & 3.5 & \pm & 1.7 & .19 & \pm & 2.35 & 3.36 & \pm & 18 \\
\hline As & & .040 & & 0.12 & \pm & $0 . c$ & & 0.040 & & & 0.017 & & & 0.017 & & 0.22 & \pm & 0.01 & 10 & \pm & 0.01 & & 0.01 & & & 0.017 & \\
\hline Se & & 0.33 & & & 33 & & & 0.32 & & & 0.33 & & & $<0.33$ & & & 33 & & & 0.33 & & & $=0.33$ & & & 0.33 & \\
\hline Mo & $\$ 9$ & \pm & 0. & & \pm & & 20 & \pm & 0. & & \pm & & 1 & \pm & & 21 & \pm & & 30 & \pm & & 19 & \pm & 22 & 0.22 & \pm & 01 \\
\hline $\mathrm{Cd}$ & & .0 & & & & & & 0.029 & & & 0. & & & 0.068 & & & .029 & & &. & & & 0.03 & & & $0.03 C$ & \\
\hline $\mathrm{Hg}$ & & \pm & & & \pm & & 8 & \pm 0 & 0. & & \pm & & & \pm & & & \pm & & & \pm & & & \pm & & 53 & \pm & 00 \\
\hline $\mathrm{Pb}$ & 0.65 & \pm & 0 & 1. & \pm & 1 & & 2 & & 1.08 & \pm & & 0.51 & \pm & & 0.63 & \pm & 0.26 & 6 & \pm & & 31 & \pm & 6 & 0.13 & \pm & 4 \\
\hline
\end{tabular}

values are expressed as average \pm standard deviation

$-\mathrm{CH}_{3}$ and $-\mathrm{CH}_{2}$ symmetric and asymmetric stretching (Ahmad et al., 2012; Coates, 2000; Hossain et al., 2011), while the latter peaks are most likely attributed to $\mathrm{C}-\mathrm{O}$ stretching (Zhao et al., 2017). Similarly, weak bands in the range $1698-1694 \mathrm{~cm}^{-1}$ appeared only in the spectra of biochars of agro-industrial origin and could be assigned to $\mathrm{C}=0$ groups
(Gai et al., 2014; Tran et al., 2016), possibly associated with the presence of carboxylic acids on these materials (Coates, 2000). In turn, both RH-derived biochars also presented a characteristic set of peaks, at 1096, 800 and 468 $\mathrm{cm}^{-1}$, which may be assigned to Si-O-Si groups (Wang et al., 2018). Finally, weak bands around 750,780 and $800 \mathrm{~cm}$ 
(a)

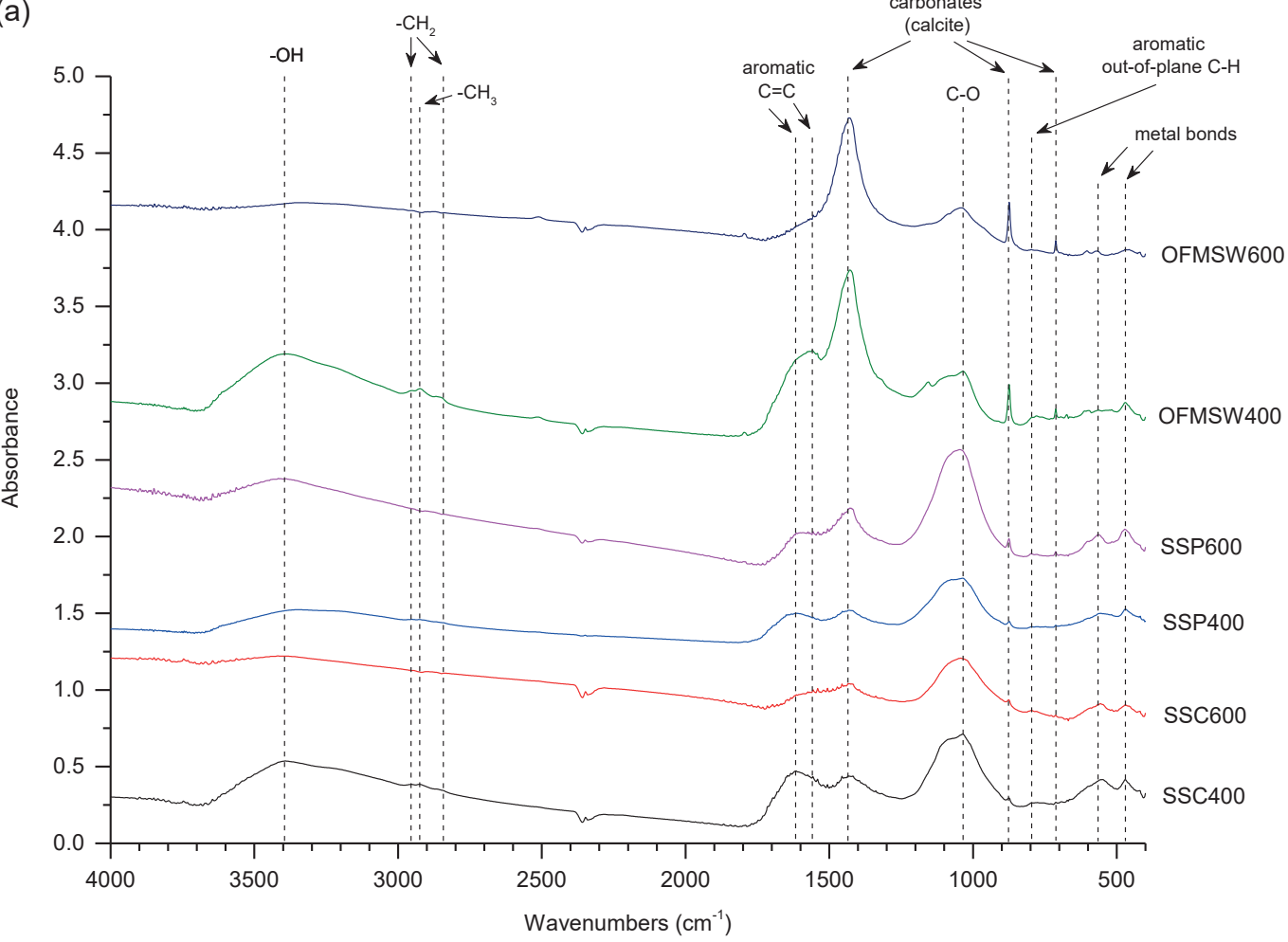

(b)

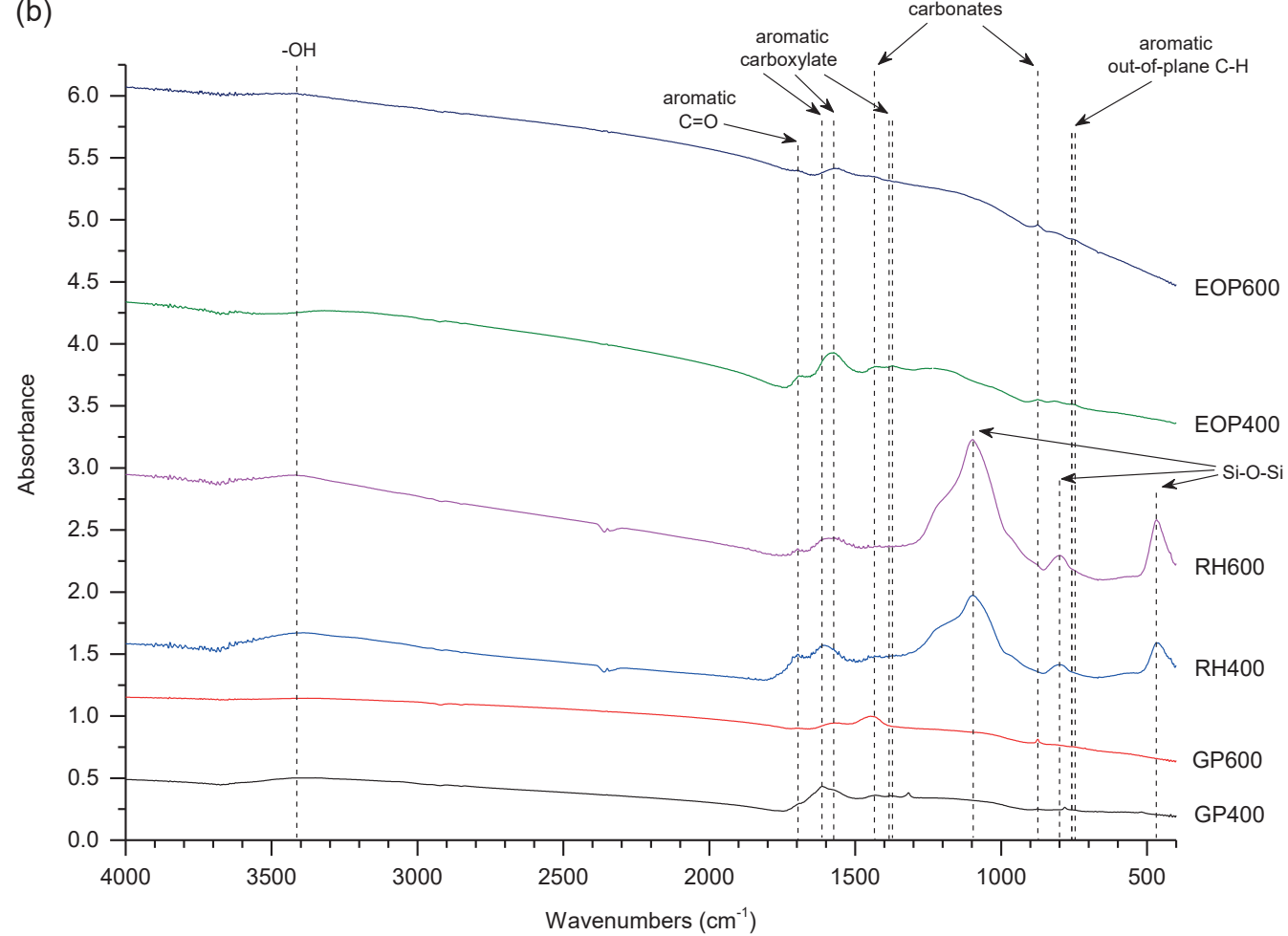

FIGURE 4: FT-IR spectra of (a) municipal and (b) agroindustrial biochars.

1 , and below $600 \mathrm{~cm}^{-1}$, could probably be associated with aromatic out-of-plane $\mathrm{C}-\mathrm{H}$ bending (Coates, 2000), and the presence of metal bonds (Hossain et al., 2011), respectively. FT-IR spectra patterns and bands similar to those of the present study have also been observed in previous studies investigating materials of similar origins (Chen et al., 2014; Lu et al., 2013; Mitchell et al., 2018; Yi et al., 2016; Taherymoosavi et al., 2017; Trakal et al., 2017; Zhang et al., 2018).

As far as the influence of pyrolysis temperature is concerned, it was noticed that the increase to $600^{\circ} \mathrm{C}$ result- 
ed in a general intensity reduction for $\mathrm{O}-\mathrm{H}$ bands around $\sim 3000 \mathrm{~cm}^{-1}$, as well as for aromatic bands around $\sim 1600$ $\mathrm{cm}^{-1}$. On the other hand, the peaks attributed to carbonates were preserved, with slight intensity variations. Moreover, while $-\mathrm{CH}_{3}$ and $-\mathrm{CH}_{2}$ bands, present on municipal biochars produced at $400^{\circ} \mathrm{C}$, were completely eliminated with the increase in temperature, such an effect was not noticed for $\mathrm{C}-\mathrm{O}$ peaks being observed for the same materials, with them being preserved. At the same time, while there was no significant change in the carboxylic acid bands of agro-industrial biochars, the increase in temperature most likely caused a reduction in carboxylate groups on the same materials, manifested by the elimination of peaks around $\sim 1380 \mathrm{~cm}^{-1}$. Finally, the bands being observed below $800 \mathrm{~cm}^{-1}$ were maintained only for municipal biochars produced at $600^{\circ} \mathrm{C}$.

\subsection{Germination assays}

According to the results, none of the biochars had a negative effect on Lepidium sativum germination, since in all assays a $100 \%$ germination rate was noted (data not shown). As far as root growth is concerned, according to a scale reported by Nieto et al. (2016), phytotoxicity is indicated when $\mathrm{GI}$ values are below $80 \%$, while values above $100 \%$ are an indication of phytostimulatory effects. Consequently, none of the examined biochars could be considered as phytotoxic at a $1 \%$ amendment rate, since $\mathrm{GI}$ values were all above $80 \%$ (Figure 5). Moreover, six biochars, specifically SSC600, SSP600, GP400, GP600, EOP400 and EOP600 could be considered as phytostimulant under the examined conditions, as a result of their corresponding Gls being greater than $100 \%$. Nevertheless, some degree of inhibition, manifested by positive RGI values (Figure 5), was noted for the remaining six biochars, specifically SSC400, SSP400, OFMSW400, OFMSW600, RH400 and RH600.

In the literature, root growth inhibition has been mainly associated with the effect that the addition of biochar can exert on the soil solution salinity, by inducing osmotic stress (Buss et al., 2016; Intani et al., 2018; Mumme et al., 2018). This was most likely the reason for the inhibition no-

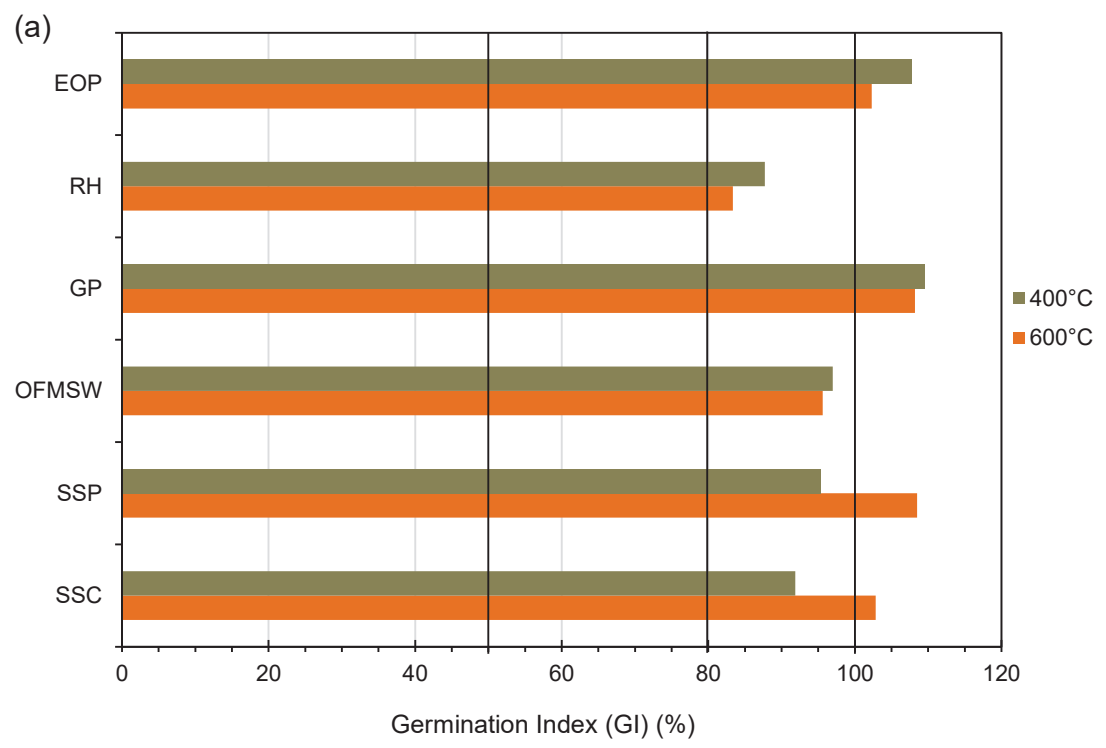

(b)

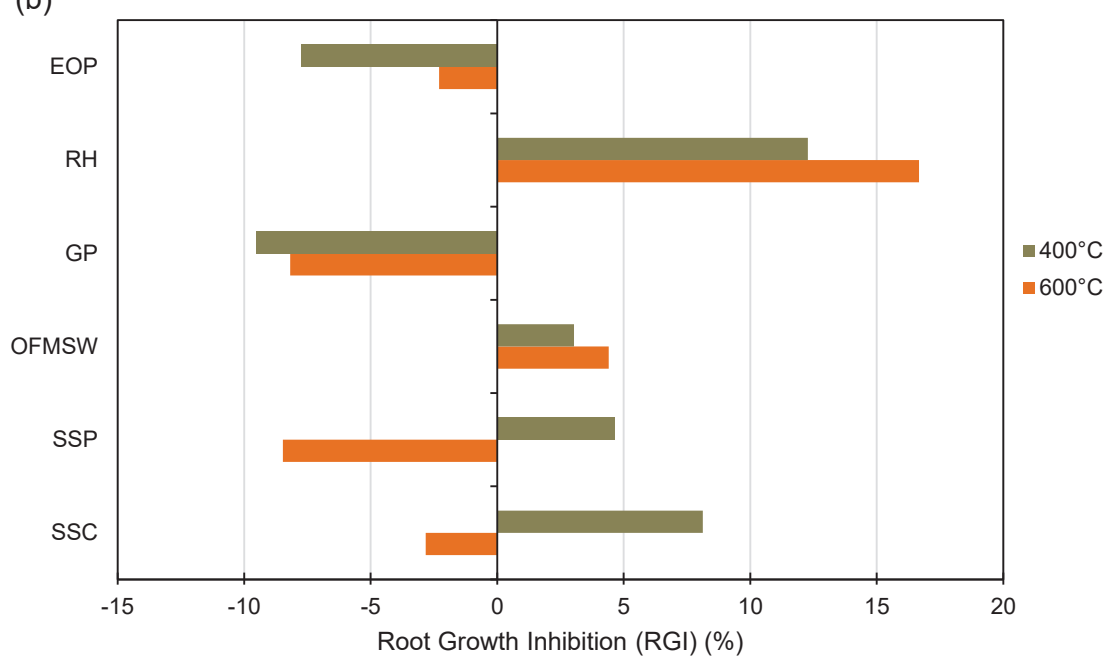

FIGURE 5: (a) Germination Index (GI) (\%) and (b) Root Growth Inhibition (RGI) (\%) obtained from germination assays with biochar amendment rate $1 \%$. 
ticed in the present study for the four biochars of municipal origin, even if this negative effect was quite moderate. Although EC values corresponding to these biochars could suggest such an effect, in reality they could only partially predict the outcome. More specifically, if only EC was considered, the municipal biochars OFMSW400, OFMSW600 and SSC400 would be more likely to cause some inhibition, as mentioned earlier (§3.3.). Nevertheless, SSP400 also showed similar results, although its EC was not equally elevated. Therefore, EC values should not be used as the sole indicator for salinity levels. Such a conclusion was also drawn in a previous study (Buss et al., 2016). What indeed contributed to the increased salinity was most probably the elevated mineral load of the biochars in question (Table 5), especially in terms of PTMs. In fact, the elevated presence of such elements, including PTMs, in more soluble form has been previously associated with osmotic stress (Rucińska-Sobkowiak, 2016). Interestingly, OFMSW-derived biochars appeared to cause a lower degree of inhibition compared with the other materials. This could be attributed to the counterbalancing between their high EC and their low cumulative PTMs content, high $\mathrm{pH}$ and high macro-nutrient ( $\mathrm{Ca}, \mathrm{K}, \mathrm{Na}, \mathrm{Mg}$ ) content. Indeed, it has been previously reported that at low amendment rates biochars with high $\mathrm{pH}$ and $\mathrm{K}$ concentrations could have a positive effect on root growth (Buss et al., 2016). Moreover, although SSC600 and SSP600 were also characterized by quite elevated PTMs loads, they showed no inhibiting effects. This could be related to their production temperature, since it has been shown that the bioavailability of PTMs is reduced for biochars produced at higher pyrolysis temperatures (Zeng et al., 2018).

As far as biochars of agroindustrial origin are concerned, the only materials that appeared to cause some inhibition were the two $\mathrm{RH}$-derived biochars, which in fact were those ultimately being associated with the highest
RGI values among all tested biochars. These results are not consistent with EC data, since GP400 and GP600, which presented higher EC values than $\mathrm{RH} 400$ and $\mathrm{RH} 600$, did not cause inhibition, but instead they exerted a phytostimulant effect on Lepidium sativum seeds, as did EOP400 and EOP600. The positive effect of GP- and EOP-derived biochars may most likely be attributed to their $\mathrm{pH}$ and macro-nutrient contents (Buss et al., 2016), as well as probably to their comparatively lower PTMs content. On the other hand, the inhibition caused by $\mathrm{RH} 400$ and $\mathrm{RH} 600$ may be mainly related to the quite pronounced $\mathrm{SiO}_{2}$ content of these biochars (Table 6), considering that $\mathrm{SiO}_{2}$ has been reported to eventually have toxic effects on root elongation at elevated concentrations (Lee et al., 2010).

It is worth mentioning that some authors have linked root growth inhibition with the presence of organic water-soluble potentially toxic elements (e.g. PAHs, phenolic compounds, etc.) on biochars (Buss and Mašek, 2014; Gell et al., 2011; Intani et al., 2018). In the present study it was unlikely that such a phenomenon took place, since all biochars were washed before being used in germination assays and this procedure would have removed toxic or inhibitory water-soluble substances (Intani et al., 2018).

\subsection{Major oxides contents}

XRF results presented in Table 6 refer only to selected biochars, chosen on the basis of the other characterization analyses and germination assays. Specifically, the selected materials were biochars of municipal origin and $\mathrm{RH}$-derived biochars. According to the data, $\mathrm{CaO}$ was present in all biochars derived from SS and OFMSW, which is consistent with the FT-IR spectra regarding the presence of calcite in biochars before ignition (Leontakianakos et al., 2015), especially in the case of OFMSW400 and OFMSW600. Other oxides being detected in considerable amounts in municipal biochars include $\mathrm{Fe}_{2} \mathrm{O}_{3}, \mathrm{SiO}_{2}, \mathrm{P}_{2} \mathrm{O}_{5}$ and $\mathrm{Al}_{2} \mathrm{O}_{3}$, while lower

TABLE 6: Major oxides content (\%) in ash samples of selected biochars, on a dry basis.

\begin{tabular}{|c|c|c|c|c|c|c|c|c|}
\hline & ssc400 & ssc600 & SSP400 & SSP600 & OFMSW400 & OFMSW600 & RH400 & RH 600 \\
\hline $\mathrm{Al}_{2} \mathrm{O}_{3}$ & 2.37 & 3.66 & 9.35 & 10.8 & 1.85 & 5.02 & 0.79 & 0.78 \\
\hline $\mathrm{CaO}$ & 21.6 & 27.7 & 28.9 & 29.3 & 48.7 & 47.1 & 0.73 & 0.89 \\
\hline $\mathrm{Cr}_{2} \mathrm{O}_{3}$ & 1.18 & 0.41 & 0.80 & 0.56 & 0.48 & 0.14 & 0.002 & 0.007 \\
\hline $\mathrm{CuO}$ & 0.09 & 0.08 & 0.13 & 0.12 & $<0.005$ & $<0.005$ & $<0.005$ & $<0.005$ \\
\hline $\mathrm{Fe}_{2} \mathrm{O}_{3}$ & 42.5 & 28.5 & 14.2 & 10.7 & 8.98 & 4.59 & 1.17 & 1.21 \\
\hline $\mathrm{K}_{2} \mathrm{O}$ & 0.75 & 1.04 & 1.84 & 2.14 & 2.01 & 3.20 & 0.06 & 0.20 \\
\hline $\mathrm{MgO}$ & 0.80 & $<0.005$ & 2.90 & 2.90 & 2.00 & 3.67 & 0.84 & 0.82 \\
\hline $\mathrm{MnO}$ & 0.43 & 0.15 & 0.15 & 0.11 & 0.17 & 0.11 & 0.15 & 0.17 \\
\hline $\mathrm{Na}_{2} \mathrm{O}$ & $<0.005$ & $<0.005$ & $<0.005$ & 2.10 & $<0.005$ & 2.55 & 0.78 & 0.54 \\
\hline $\mathrm{NiO}$ & 0.73 & 0.14 & 0.25 & 0.15 & 0.21 & 0.06 & 0.02 & 0.02 \\
\hline $\mathrm{P}_{2} \mathrm{O}_{5}$ & 11.4 & 15.0 & 16.0 & 16.0 & 2.57 & 2.48 & 0.13 & 0.24 \\
\hline $\mathrm{PbO}$ & $<0.005$ & $<0.005$ & 0.25 & $<0.005$ & $<0.005$ & $<0.005$ & $<0.005$ & $<0.005$ \\
\hline $\mathrm{SiO}_{2}$ & 15.4 & 20.7 & 22.5 & 22.8 & 23.3 & 25.3 & 89.2 & 97.1 \\
\hline $\mathrm{SO}_{3}$ & 0.50 & $<0.005$ & 0.28 & 0.22 & 7.27 & 5.40 & $<0.005$ & $<0.005$ \\
\hline $\mathrm{TiO}_{2}$ & 0.90 & 1.13 & 1.13 & 1.12 & 0.63 & 0.85 & $<0.005$ & $<0.005$ \\
\hline $\mathrm{ZnO}$ & 0.28 & 0.24 & 0.38 & 0.38 & 0.11 & 0.12 & $<0.005$ & $<0.005$ \\
\hline
\end{tabular}


percentages of metal oxides in these materials are consistent with the considerations regarding metal bonds made in §3.6. Similarly, the results obtained for $\mathrm{RH} 400$ and $\mathrm{RH} 600$ confirmed the highly significant presence of $\mathrm{SiO}_{2}$ in these materials, again corroborating the FT-IR analysis.

\section{CONCLUSIONS}

The present study focused on the characterization of twelve biochars derived from six types of biomass and produced at two temperatures, aiming at evaluating their potential use in agronomic and environmental applications. Both pyrolysis temperature and feedstock type appeared to have a significant effect on biochar characteristics, with the data implying various potential applications for the examined materials.

In terms of agronomic application, based on the characterization results, biochars generated at $400^{\circ} \mathrm{C}$ may be more able to improve soil characteristics, as well as enhance nutrient and water retention, compared to higher-temperature materials, due to their lower bulk density, as well as higher CEC and hydrophilicity, respectively. On the other hand, biochars obtained at $600^{\circ} \mathrm{C}$ could offer greater carbon stability due to their higher aromaticity, and thus be more suitable for carbon sequestration. Moreover, almost all biochars of agroindustrial origin, as well as some biochars of municipal origin may be good candidates for ameliorating acid soils, as a result of their high $\mathrm{pH}$ values. Although the germination assays showed no phytotoxic effects of the investigated biochars on Lepidium sativum seeds, under the examined conditions and at a soil amendment rate of $1 \%$, prior to real-case use of these materials at rates $>1 \%$, a thorough assessment of their potential inhibitory or toxic effects should be performed in relation to the specific application for which they are intended (type of soil, type of plant, etc.). Attention should be given on the biochars' salinity and mineral contents, especially in terms of bioavailability.

As far as environmental applications are concerned, higher CEC as well as the stronger presence of surface functional groups in biochars produced at $400^{\circ} \mathrm{C}$, suggest that these materials may be more suitable for metal retention in both soil and aqueous media compared with those produced at $600^{\circ} \mathrm{C}$. Moreover, the presence of functional groups coupled with the higher polarity of the low temperature biochars is an indication of a potentially better performance with polar organic contaminants. On the contrary, biochars produced at $600^{\circ} \mathrm{C}$, being characterized by higher specific surface area and higher hydrophobicity, may be more effective in remediating contamination by non-polar organic compounds. Furthermore, $\mathrm{pH}$ values suggest that several of the studied biochars could be effectively used to induce metal precipitation, while $\mathrm{pH}_{\mathrm{PZC}}$ values reveal a potential affinity of OFMSW400, OFMSW600 and GP600 also for anionic contaminants.

\section{AKNOWLEDGEMENTS}

We acknowledge support of this work by the project INVALOR: Research Infrastructure for Waste Valorization and Sustainable Management" (MIS 5002495) which is implemented under the Action "Reinforcement of the Research and Innovation Infrastructure", funded by the Operational Programme "Competitiveness, Entrepreneurship and Innovation" (NSRF 2014-2020) and co-financed by Greece and the European Union (European Regional Development Fund).

\section{REFERENCES}

Agrafioti, E., Bouras, G., Kalderis, D., \& Diamadopoulos, E. (2013). Biochar production by sewage sludge pyrolysis. Journal of Analytical and Applied Pyrolysis, 101, 72-78. https://doi.org/10.1016/j. jaap.2013.02.010

Ahmad, M., Lee, S.S., Dou, X., Mohan, D., Sung, J.K., Yang, J.E., \& Ok, Y.S. (2012). Effects of pyrolysis temperature on soybean stover-and peanut shell-derived biochar properties and TCE adsorption in water. Bioresource Technology, 118, 536-544. https://doi. org/10.1016/j.biortech.2012.05.042

Ahmad, M., Rajapaksha, A.U., Lim, J.E., Zhang, M., Bolan, N., Mohan, D., Vithanage, M., Lee, S.S., \& Ok, Y.S. (2014). Biochar as a sorbent for contaminant management in soil and water: $A$ review. Chemosphere, 99, 19-23. https://doi.org/10.1016/j. chemosphere.2013.10.071

Ahmedna, M., Johns, M.M., Clarke, S.J., Marshall, W.E., \& Rao, R.M. (1997). Potential of agricultural by-product-based activated carbons for use in raw sugar decolourisation. Journal of the Science of Food and Agriculture, 75(1), 117-124. https://doi.org/10.1002/ (SICI)1097-0010(199709)75:1<117::AID-JSFA850>3.0.CO;2-M

Aller, M.F. (2016). Biochar properties: Transport, fate, and impact. Critical Reviews in Environmental Science and Technology, 46(14-15), 1183-1296. https://doi.org/10.1080/10643389.2016.1212368

Al-Wabel, M.I., Al-Omran, A., El-Naggar, A.H., Nadeem, M., \& Usman, A.R.A. (2013). Pyrolysis temperature induced changes in characteristics and chemical composition of biochar produced from conocarpus wastes. Bioresource Technology, 131, 374-379. https:// doi.org/10.1016/j.biortech.2012.12.165

APHA. (1992). Method 2540G. Standard Methods for the Examination of Water and Wastewater.

ASTM D1762-84 (2004). Standard Test Method for Chemical Analysis of Wood Charcoal. ASTM International, West Conshohocken, PA, 2004.

ASTM E897-88 (2004). Standard Test Method for Volatile Matter in the Analysis Sample of Refuse-Derived Fuel. ASTM International, West Conshohocken, PA, 2004.

Belyaeva, O.N., Haynes, R.J., \& Sturm, E.C. (2012). Chemical, physical and microbial properties and microbial diversity in manufactured soils produced from co-composting green waste and biosolids. Waste Management, 32(12), 2248-2257. https://doi.org/10.1016/j. wasman.2012.05.034

Buss, W., Graham, M.C., Shepherd, J.G., \& Mašek, O. (2016). Risks and benefits of marginal biomass-derived biochars for plant growth. Science of the Total Environment, 569-570, 496-506. https://doi. org/10.1016/j.scitotenv.2016.06.129

Buss, W., \& Mašek, O. (2014). Mobile organic compounds in biochar-a potential source of contamination-phytotoxic effects on cress seed (Lepidium sativum) germination. Journal of Environmental Management, 137, 111-119. https://doi.org/10.1016/j.jenvman.2014.01.045

Cao, X., \& Harris, W. (2010). Properties of dairy-manure-derived biochar pertinent to its potential use in remediation. Bioresource Technology, 101(14), 5222-5228. https://doi.org/10.1016/j.biortech.2010.02.052

Chen, B., Zhou, D., \& Zhu, L. (2008). Transitional adsorption and partition of nonpolar and polar aromatic contaminants by biochars of pine needles with different pyrolytic temperatures. Environmental Science \& Technology, 42(14), 5137-5143. https://doi. org/10.1021/es8002684

Chen, T., Zhang, Y., Wang, H., Lu, W., Zhou, Z., Zhang, Y., \& Ren, L. (2014). Influence of pyrolysis temperature on characteristics and heavy metal adsorptive performance of biochar derived from municipal sewage sludge. Bioresource Technology, 164, 47-54. https://doi. org/10.1016/j.biortech.2014.04.048 
Coates, J. (2000). Interpretation of Infrared Spectra, A Practical Approach. Encyclopedia of Analytical Chemistry, 12, 10815-10837. https://doi.org/10.1002/9780470027318.a5606

Colantoni, A., Evic, N., Lord, R., Retschitzegger, S., Proto, A.R., Gallucci, F., \& Monarca, D. (2016). Characterization of biochars produced from pyrolysis of pelletized agricultural residues. Renewable and Sustainable Energy Reviews, 64, 187-194. https://doi.org/10.1016/j. rser.2016.06.003

Domene, X., Enders, A., Hanley, K., \& Lehmann, J. (2015). Ecotoxicological characterization of biochars: Role of feedstock and pyrolysis temperature. Science of the Total Environment, 512-513, 552-561. https://doi.org/10.1016/j.scitotenv.2014.12.035

EBC (2012). 'European Biochar Certificate - Guidelines for a Sustainable Production of Biochar.' European Biochar Foundation (EBC), Arbaz, Switzerland. http://www.european- biochar.org/en/download. Version 6.3E of 14th August 2017.

EC. European Commission. Directive 86/278/EEC on the protection of the environment and in particular of the soil. When sewage sludge is used in agriculture, 2009. https://eur-lex.europa.eu/eli/ $\operatorname{dir} / 1986 / 278 / 2009-04-20$

Elkhalifa, S., Al-Ansari, T., Mackey, H.R., \& McKay, G. (2019). Food waste to biochars through pyrolysis: A review. Resources, Conservation and Recycling, 144, 310-320. https://doi.org/10.1016/j.resconrec.2019.01.024

Enders, A., Hanley, K., Whitman, T., Joseph, S., \& Lehmann, J. (2012). Characterization of biochars to evaluate recalcitrance and agronomic performance. Bioresource Technology, 114, 644-653. https://doi.org/10.1016/j.biortech.2012.03.022

EUROSTAT (2020). Available at: https://ec.europa.eu/eurostat (last visited on $8 / 7 / 2020$ )

Fountoulakis, M.S., Drakopoulou, S., Terzakis, S., Georgaki, E., \& Manios, T. (2008). Potential for methane production from typical Mediterranean agro-industrial by-products. Biomass and Bioenergy 32, 155-161. https://doi.org/10.1016/j.biombioe.2007.09.002

Fryda, L., Visser, R., \& Schmidt, J. (2019). Biochar replaces peat in horticulture: environmental impact assessment of combined biochar \& bioenergy production. Detritus, 5, 132-149. doi:10.31025/26114135/2019.13778

Gai, X., Wang, H., Liu, J., Zhai, L., Liu, S., Ren, T., \& Liu, H. (2014). Effects of feedstock and pyrolysis temperature on biochar adsorption of ammonium and nitrate. PLoS ONE, 9(12), 1-19. https://doi. org/10.1371/journal.pone.0113888

Gell, K., van Groenigen, J.W., \& Cayuela, M.L. (2011). Residues of bioenergy production chains as soil amendments: Immediate and temporal phytotoxicity. Journal of Hazardous Materials, 186(2-3), 2017-2025. https://doi.org/10.1016/j.jhazmat.2010.12.105

Gómez, N., Rosas, J.G., Cara, J., Martínez, O., Alburquerque, J.A., \& Sánchez, M.E. (2016). Slow pyrolysis of relevant biomasses in the Mediterranean basin. Part 1. Effect of temperature on process performance on a pilot scale. Journal of Cleaner Production, 120 181-190. https://doi.org/10.1016/j.jclepro.2014.10.082

Gunarathne, V., Ashiq, A., Ramanayaka, S., Wijekoon, P., \& Vithanage, M. (2019). Biochar from municipal solid waste for resource recovery and pollution remediation. Environmental Chemistry Letters, 1-11. https://doi.org/10.1007/s10311-019-00866-0

Hossain, M.K., Strezov, V., Chan, K.Y., Ziolkowski, A., \& Nelson, P.F. (2011). Influence of pyrolysis temperature on production and nutrient properties of wastewater sludge biochar. Journal of Environmental Management, 92(1), 223-228. https://doi.org/10.1016/j. jenvman.2010.09.008

IBI (2015). Standardized Product Definition and Product Testing Guidelines for Biochar That Is Used in Soil. International Biochar Initiative, Version 2.1, (November 23rd 2015). https://www.biochar-international.org/wp-content/uploads/2018/04/IBI_Biochar_ Standards_V2.1_Final.pdf

Ibn Ferjani, A., Jeguirim, M., Jellali, S., Limousy, L., Courson, C., Akrout, H., Thevenin, N., Ruidavets, L. Muller, A., \& Bennici, S. (2019). The use of exhausted grape marc to produce biofuels and biofertilizers: Effect of pyrolysis temperatures on biochars properties. Renewable and Sustainable Energy Reviews, 107, 425-433. https:// doi.org/10.1016/j.rser.2019.03.034

Inguanzo, M., Domínguez, A., Menéndez, J.A., Blanco, C.G., \& Pis, J.J. (2002). On the Pyrolysis of Sewage Sludge: The Influence of Pyrolysis Temperature on Biochar, Liquid and Gas Fractions. Journal of Analytical and Applied Pyrolysis, 63(1), 209-222. https://doi. org/10.1016/S0165-2370(01)00155-3
Intani, K., Latif, S., Islam, M. S., \& Müller, J. (2018). Phytotoxicity of corncob biochar before and after heat treatment and washing. Sustainability (Switzerland), 11(1). https://doi.org/10.3390/su11010030

Jimoh, O. A., Otitoju, T. A., Hussin, H., Ariffin, K. S., \& Baharun, N. (2017). Understanding the precipitated calcium carbonate (PCC) production mechanism and its characteristics in the liquid-gas system using milk of lime (MOL) suspension. South African Journal of Chemistry, 70, 1-7. http://dx.doi.org/10.17159/0379-4350/2017/ v70a1

Jin, H., Capareda, S., Chang, Z., Gao, J., Xu, Y., \& Zhang, J. (2014). Biochar pyrolytically produced from municipal solid wastes for aqueous As(V) removal: Adsorption property and its improvement with $\mathrm{KOH}$ activation. Bioresource Technology, 169, 622-629. https://doi. org/10.1016/j.biortech.2014.06.103

Kah, M., Sun, H., Sigmund, G., Hüffer, T., \& Hofmann, T. (2016). Pyrolysis of waste materials: Characterization and prediction of sorption potential across a wide range of mineral contents and pyrolysis temperatures. Bioresource Technology, 214, 225-233. https://doi. org/10.1016/j.biortech.2016.04.091

Lee, C.W., Mahendra, S., Zodrow, K., Li, D., Tsai, Y.C., Braam, J., \& Alvarez, P.J.J. (2010). Developmental phytotoxicity of metal oxide nanoparticles to Arabidopsis thaliana. Environmental Toxicology and Chemistry: An International Journal, 29(3), 669-675. https:// doi.org/10.1002/etc.58

Leontakianakos, G., Baziotis, I., Papandreou, A., Kanellopoulou, D., Stathopoulos, V.N., \& Tsimas, S. (2015). A comparative study of the physicochemical properties of $\mathrm{Mg}$-rich and $\mathrm{Ca}$-rich quicklimes and their effect on reactivity. Materials and Structures/Materiaux et Constructions, 48(11), 3735-3753. https://doi.org/10.1617/ s11527-014-0436-y

Li, D.-C., \& Jiang, H. (2017). The thermochemical conversion of non-lignocellulosic biomass to form biochar: A review on characterizations and mechanism elucidation. Bioresource Technology, 246, 57-68. https://doi.org/10.1016/j.biortech.2017.07.029

Li, H., Dong, X., da Silva, E.B., de Oliveira, L.M., Chen, Y., \& Ma, L.Q. (2017). Mechanisms of metal sorption by biochars: Biochar characteristics and modifications. Chemosphere, 178, 466-478. https://doi.org/10.1016/j.chemosphere.2017.03.072

Lu, H., Zhang, W., Wang, S., Zhuang, L., Yang, Y., \& Qiu, R. (2013). Characterization of sewage sludge-derived biochars from different feedstocks and pyrolysis temperatures. Journal of Analytical and Applied Pyrolysis, 102, 137-143. https://doi.org/10.1016/j. jaap.2013.03.004

Luo, F., Song, J., Xia, W., Dong, M., Chen, M., \& Soudek, P. (2014). Characterization of contaminants and evaluation of the suitability for land application of maize and sludge biochars. Environmental Science and Pollution Research, 21(14), 8707-8717. https://doi. org/10.1007/s11356-014-2797-8

Manolikaki, I.I., Mangolis, A., \& Diamadopoulos, E. (2016). The impact of biochars prepared from agricultural residues on phosphorus release and availability in two fertile soils. Journal of Environmental Management, 181, 536-543. https://doi.org/10.1016/j.jenvman.2016.07.012

Mitchell, K., Trakal, L., Sillerova, H., Avelar-González, F.J., Guerrero-Barrera, A.L., Hough, R., \& Beesley, L. (2018). Mobility of As, $\mathrm{Cr}$ and Cu in a contaminated grassland soil in response to diverse organic amendments; a sequential column leaching experiment. Applied Geochemistry, 88, 95-102. https://doi.org/10.1016/j.apgeochem.2017.05.020

Mukherjee, A., Zimmerman, A.R., \& Harris W. (2011). Surface chemistry variations among a series of laboratory-produced biochars. Geoderma, 163(3-4), 247-255. https://doi.org/10.1016/j.geoderma.2011.04.021

Mumme, J., Getz, J., Prasad, M., Lüder, U., Kern, J., Mašek, O., \& Buss, W. (2018). Toxicity screening of biochar-mineral composites using germination tests. Chemosphere, 207, 91-100. https://doi. org/10.1016/j.chemosphere.2018.05.042

Nasir, M., Rahmawati, T., \& Dara, F. (2019). Synthesis and characterization of biochar from crab shell by pyrolysis. IOP Conference Series: Materials Science and Engineering, 553(1). https://doi. org/10.1088/1757-899X/553/1/012031

Nieto, A., Gascó, G., Paz-Ferreiro, J., Fernández, J. M., Plaza, C., \& Méndez, A. (2016). The effect of pruning waste and biochar addition on brown peat based growing media properties. Scientia Horticulturae, 199, 142-148. https://doi.org/10.1016/j.scienta.2015.12.012 
Oh, T.-K., Choi, B., Shinogi, Y., \& Chikushi, J. (2012). Characterization of biochar derived from three types of biomass. J. Fac. Agric. Kyushu Univ., 57(1), 61-66

Oleszczuk, P., \& Hollert, H. (2011). Comparison of sewage sludge toxicity to plants and invertebrates in three different soils. Chemosphere, 83(4), 502-509. https://doi.org/10.1016/j. chemosphere.2010.12.061

Pariyar, P., Kumari, K., Jain, M. K., \& Jadhao, P.S. (2020). Evaluation of change in biochar properties derived from different feedstock and pyrolysis temperature for environmental and agricultural application. Science of the Total Environment, 713, 136433. https://doi. org/10.1016/j.scitotenv.2019.136433

Pellera, F.-M., \& Gidarakos, E. (2015). Effect of dried olive pomace - derived biochar on the mobility of cadmium and nickel in soil. Journal of Environmental Chemical Engineering, 3(2), 1163-1176. https:// doi.org/10.1016/j.jece.2015.04.005

Pituello, C., Francioso, O., Simonetti, G., Pisi, A., Torreggiani, A., Berti, A., \& Morari, F. (2015). Characterization of chemical-physical, structural and morphological properties of biochars from biowastes produced at different temperatures. Journal of Soils and Sediments, 15(4), 792-804. https://doi.org/10.1007/s11368-0140964-7

Rajkovich, S., Enders, A., Hanley, K., Hyland, C., Zimmerman, A.R., \& Lehmann, J. (2012). Corn growth and nitrogen nutrition after additions of biochars with varying properties to a temperate soil. Biology and Fertility of Soils, 48(3), 271-284. https://doi.org/10.1007/s00374011-0624-7

Randolph, P., Bansode, R.R., Hassan, O.A., Rehrah, D., Ravella, R., Reddy, M.R., Watts, D.W., Novak, J.M., \& Ahmedna, M. (2017). Effect of biochars produced from solid organic municipal waste on soil quality parameters. Journal of Environmental Management, 192, 271-280. https://doi.org/10.1016/j.jenvman.2017.01.061

Rehrah, D., Reddy, M.R., Novak, J.M., Bansode, R.R., Schimmel, K.A., Yu, J., Watts, D.W., \& Ahmedna, M. (2014). Production and characterization of biochars from agricultural by-products for use in soil quality enhancement. Journal of Analytical and Applied Pyrolysis, 108, 301-309. https://doi.org/10.1016/j.jaap.2014.03.008

Rehrah, D., Bansode, R.R., Hassan, O., \& Ahmedna, M. (2016). Physico-chemical characterization of biochars from solid municipa waste for use in soil amendment. Journal of Analytical and Applied Pyrolysis, 118, 42-53. https://doi.org/10.1016/j.jaap.2015.12.022

Rucińska-Sobkowiak, R. (2016). Water relations in plants subjected to heavy metal stresses. Acta Physiologiae Plantarum, 38. https:// doi.org/10.1007/s11738-016-2277-5

Rybova K., Burcin B., Slavik, J. (2018). Spatial and non-spatial analysis of socio-demographic aspects influencing municipal solid waste generation in the czech republic. Detritus, 1(1), 3 -7. doi: 10.26403/ detritus/2018.2

Shen, Z., Zhang, Y., McMillan, O., Jin, F., \& Al-Tabbaa, A. (2017). Characteristics and mechanisms of nickel adsorption on biochars produced from wheat straw pellets and rice husk. Environmental Science and Pollution Research, 24(14), 12809-12819. https://doi. org/10.1007/s11356-017-8847-2

Singh, B., Dolk, M.M., Shen, Q., \& Camps-Arbestain, M. (2017). Biochar $\mathrm{pH}$, electrical conductivity and liming potential. In Biochar: A Guide to Analytical Methods, Balwant Singh, et al. (Eds), Csiro Publishing, Clayton, Australia, 23-38. https://doi.org/10.1071/9781486305100

Song, W., \& Guo, M. (2012). Quality variations of poultry litter biochar generated at different pyrolysis temperatures. Journal of Analytical and Applied Pyrolysis, 94, 138-145. https://doi.org/10.1016/j. jaap.2011.11.018

Stefaniuk, M., \& Oleszczuk, P. (2015). Characterization of biochars produced from residues from biogas production. Journal of Analytical and Applied Pyrolysis, 115, 157-165. https://doi.org/10.1016/j. jaap.2015.07.011

Stylianou, M., Christou, A., Dalias, P., Polycarpou, P., Michael, C., Agapiou, A., Papanastasiou, P., \& Fatta-Kassinos, D. (2020). Physicochemical and structural characterization of biochar derived from the pyrolysis of biosolids, cattle manure and spent coffee grounds. Journal of the Energy Institute, 93(5), 2063-2073. https://doi. org/10.1016/j.joei.2020.05.002
Suliman, W., Harsh, J.B., Abu-Lail, N.I., Fortuna, A.-M., Dallmeyer, I., \& Garcia-Perez, M. (2016). Influence of feedstock source and pyrolysis temperature on biochar bulk and surface properties. Biomass and Bioenergy, 84, 37-48. https://doi.org/10.1016/j.biombioe.2015.11.010

Tag, A.T., Duman, G., Ucar, S., \& Yanik, J. (2016). Effects of feedstock type and pyrolysis temperature on potential applications of biochar. Journal of Analytical and Applied Pyrolysis, 120, 200-206. https://doi.org/10.1016/j.jaap.2016.05.006

Taherymoosavi, S., Verheyen, V., Munroe, P., Joseph, S., \& Reynolds, A. (2017). Characterization of organic compounds in biochars derived from municipal solid waste. Waste Management, 67, 131142. https://doi.org/10.1016/j.wasman.2017.05.052

Tan, X., Liu, Y., Zeng, G., Wang, X., Hu, X., Gu, Y., \& Yang, Z. (2015). Application of biochar for the removal of pollutants from aqueous solutions. Chemosphere, 125, 70-85. https://doi.org/10.1016/j. chemosphere.2014.12.058

Taskin, E., de Castro Bueno, C., Allegretta, I., Terzano, R., Rosa, A.H., \& Loffredo, E. (2019). Multianalytical characterization of biochar and hydrochar produced from waste biomasses for environmental and agricultural applications. Chemosphere, 233, 422-430. https://doi. org/10.1016/j.chemosphere.2019.05.204

Trakal, L., Raya-Moreno, I., Mitchell, K., \& Beesley, L. (2017). Stabilization of metal(loid)s in two contaminated agricultural soils: Comparing biochar to its non-pyrolysed source material. Chemosphere, 181, 150-159. https://doi.org/10.1016/j.chemosphere.2017.04.064

Tran, H. N., You, S. J., \& Chao, H. P. (2016). Effect of pyrolysis temperatures and times on the adsorption of cadmium onto orange peel derived biochar. Waste Management \& Research, 34(2), 129-138. https://doi.org/10.1177/0734242X15615698

Uchimiya, M., Klasson, K.T., Wartelle, L.H., \& Lima, I.M. (2011). Influence of soil properties on heavy metal sequestration by biochar amendment: 1 . Copper sorption isotherms and the release of cations. Chemosphere, 82(10), 1431-1437. https://doi.org/10.1016/j. chemosphere.2010.11.050

US EPA (1986). Method 9081. Cation exchange capacity of soils (sodium acetate)

Wang, Y., Xiao, X., \& Chen, B. (2018). Biochar Impacts on Soil Silicon Dissolution Kinetics and their Interaction Mechanisms. Scientific Reports, 8(1), 1-11. https://doi.org/10.1038/s41598-018-26396-3

Yao, Y., Gao, B., Inyang, M., Zimmerman, A.R., Cao, X., Pullammanappallil, P., \& Yang, L. (2011). Biochar derived from anaerobically digested sugar beet tailings: Characterization and phosphate removal potential. Bioresource Technology, 102(10), 6273-6278. https:// doi.org/10.1016/j.biortech.2011.03.006

Yargicoglu, E.N., Sadasivam, B.Y., Reddy, K.R., Spokas, K. (2015). Physical and chemical characterization of waste wood derived biochars. Waste Management, 36, 256-268. https://doi.org/10.1016/j.wasman.2014.10.029

Yi, S., Gao, B., Sun, Y., Wu, J., Shi, X., Wu, B., \& Hu, X. (2016). Removal of levofloxacin from aqueous solution using rice-husk and wood-chip biochars. Chemosphere, 150, 694-701. https://doi.org/10.1016/j. chemosphere.2015.12.112

Zeng, X., Xiao, Z., Zhang, G., Wang, A., Li, Z., Liu, Y., Wang, H., Zeng, Q., Liang, Y., \& Zou, D. (2018). Speciation and bioavailability of heavy metals in pyrolytic biochar of swine and goat manures. ournal of Analytical and Applied Pyrolysis, 132, 82-93. https://doi. org/10.1016/j.jaap.2018.03.012

Zhao, S.-X., Ta, N., \& Wang, X.-D. (2017). Effect of temperature on the structural and physicochemical properties of biochar with apple tree branches as feedstock material. Energies, 10(9), 1293. https:// doi.org/10.3390/en10091293

Zhang, K., Sun, P., Faye, M.C.A., \& Zhang, Y. (2018). Characterization of biochar derived from rice husks and its potential in chlorobenzene degradation. Carbon, 130, 730-740. https://doi.org/10.1016/j.carbon.2018.01.036 